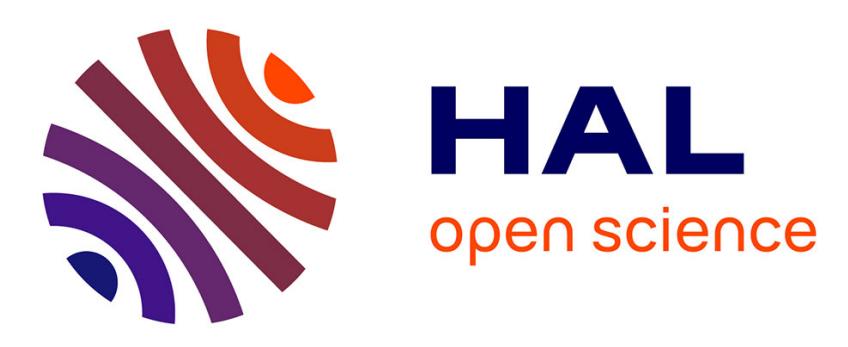

\title{
Reaching the human scale: A spatial and temporal downscaling approach to the archaeological implications of paleoclimate data
}

\author{
Daniel Contreras, Joel Guiot, Romain Suarez, Alan Kirman
}

\section{To cite this version:}

Daniel Contreras, Joel Guiot, Romain Suarez, Alan Kirman. Reaching the human scale: A spatial and temporal downscaling approach to the archaeological implications of paleoclimate data. Journal of Archaeological Science, 2018, 93, pp.54-67. 10.1016/j.jas.2018.02.013 . hal-01789786

\author{
HAL Id: hal-01789786 \\ https://hal.science/hal-01789786
}

Submitted on 16 May 2018

HAL is a multi-disciplinary open access archive for the deposit and dissemination of scientific research documents, whether they are published or not. The documents may come from teaching and research institutions in France or abroad, or from public or private research centers.
L'archive ouverte pluridisciplinaire HAL, est destinée au dépôt et à la diffusion de documents scientifiques de niveau recherche, publiés ou non, émanant des établissements d'enseignement et de recherche français ou étrangers, des laboratoires publics ou privés. 
REACHING THE HUMAN SCALE:

\title{
A SPATIAL AND TEMPORAL DOWNSCALING APPROACH TO THE ARCHAEOLOGICAL IMPLICATIONS OF PALEOCLIMATE DATA
}

\author{
Daniel Contreras ${ }^{1,2}$, Joel Guiot ${ }^{3}$, Romain Suarez ${ }^{4}$, and Alan Kirman ${ }^{5}$
}

(1) Institut Méditerranéen de Biodiversité et d'Ecologie marine et continentale (IMBE), Aix Marseille Université, CNRS, IRD, Avignon Université, Aix-en-Provence, France (danielalexandercontreras@gmail.com)

(2) Groupement de recherche en économie quantitative d'Aix-Marseille (GREQAM), Aix-Marseille Université, France

(3) Aix-Marseille Université, CNRS, IRD, Coll France, CEREGE, Aix-en-Provence, France

(4) Aix-Marseille Université, LabEx OT-Med, Aix-en-Provence, France

(5) CAMS-EHESS, Ecole des Hautes Etudes en Sciences Sociales and Aix-Marseille Université

\begin{abstract}
Assessing the implications of paleoclimatic and paleoenvironmental data at temporal and spatial scales that would have directly intersected with human decision-making and activity is a fundamental archaeological challenge. This paper addresses this challenge by presenting a spatial and temporal downscaling method that can provide quantitative highspatio-temporal-resolution estimates of the local consequences of climatic change. Using a case study in Provence (France) we demonstrate that a centennial-scale Mediterranean-wide model of Holocene climate, in conjunction with modern geospatial and climate data, can be used to generate explicit and solidly-grounded monthly estimates of temperature, precipitation, and cloudiness at landscape scales and with annual resolution, enabling consideration of climate variability at human scales and meeting the data requirements of socioecological models focused on human activity. While the results are not reconstructions - that is, particular values are single realizations, consistent with the coarse-grained data but not individually empirically derived nor unique solutions - they provide a more suitable basis for assessing the human consequences of climate change than can coarse-grained data.
\end{abstract}

Keywords: downscaling; resolution; scale; paleoclimate; climate change; humanenvironment interactions

\section{Introduction}

Interpreting the consequences of environmental change for past peoples is a longstanding concern of archaeology, and often the 'hook' for paleoclimatic or paleoenvironmental studies as well. Developing explanatory links has remained a persistent challenge, however, and studies that are able to move beyond correlation to causation remain rare. Much of this difficulty results from the challenge of assessing the implications of paleoclimatic and paleoenvironmental data at temporal and spatial scales that would have been directly relevant to human decision-making and activity. We address this problem by developing a spatial and temporal downscaling method that can provide quantitative highspatiotemporal-resolution estimates of the local consequences of climatic change. Using a case study in Provence we demonstrate that a centennial-scale Mediterranean-wide model of Holocene climate, in conjunction with modern geographic and climatic data, can be used to generate solidly-grounded monthly estimates of temperature, precipitation, and cloudiness at a 
$300 \mathrm{~m}$ spatial scale and with annual resolution. These results, it must be emphasized, are not reconstructions: they are single realizations consistent with coarse-grained data, but individual values are not directly empirically derived. Downscaling generates one set of values consistent with the coarse-grained input data, but the results are not unique solutions (Bierkens et al., 2000, p. 111; Wu and Li, 2006, p. 35). However, they provide a more suitable basis for assessing the human consequences of climate change than can coarsegrained data, as analyses of past human-environment interaction grounded in anthropological archaeology require high spatial and temporal resolution. Anthropological archaeological explanation relies on theoretical models of human behavior and decision-making that are necessarily grounded in human experience: spatial and temporal scales measured in hectares and years rather than regions and centuries.

In this paper we review these issues of scale and resolution in the study of past humanenvironment interactions before demonstrating how spatial and temporal downscaling has the potential to address the challenge of relating spatially and temporally coarse-grained paleoclimate data to fine-grained anthropologically-grounded explanations of past human behavior. We explore the application of spatial downscaling of paleoclimate data to provide high spatial resolution, and temporal downscaling to provide high temporal resolution. This combined approach enables consideration of landscape-scale spatial variability in past climates (vital in topographically diverse landscapes in which climate effects would not have been spatially uniform) as well as consideration of interannual variability. Such downscaling is a necessary tool for considering the human consequences of climate changes documented in spatial and temporal aggregate.

\section{Scale and Resolution in the study of past human-environment interactions}

Description and analysis of past human-environment interactions, particularly over the long-term, comprises a fundamental goal of archaeology. This focus underlies several of the recently-articulated "grand challenges for archaeology" (Kintigh et al., 2014), and has been singled out in $21^{\text {st }}$ century discussions of the discipline as central to archaeology's contribution to interdisciplinary efforts to understand past and present socioenvironmental systems, as well as of pressing modern relevance (e.g., Van der Leeuw and Redman, 2002; Smith et al., 2012).

Analysis of long-term human-environment interactions promises improved understanding of both cultural and environmental trajectories, and provides a tool for examining the anthropogenic component of past and modern environment and climate. It is fundamental to ongoing debates over the Anthropocene, in which archaeologists, paleoenvironmental scientists, and geologists dispute the antiquity, character, and significance of that period (e.g., Braje, 2015; Crutzen and Steffen, 2003; Erlandson and Braje, 2013; Morrison, 2015; Ruddiman, 2013; Smith and Zeder, 2013; Zalasiewicz et al., 2015).

However, such analysis continues to be challenged by problems of spatial and temporal scale and resolution (cf. Contreras, 2017). The problem is not unique to archaeology, but central also to modern discussions of climate change: what are the local consequences of global climate? In analytical terms, how can we move from global summary data to local characterizations that enable consideration of the human consequences of climate change? Moreover, as the global effects of local behaviors can also be significant for largescale modeling, the inverse problem is also an important focus: in order to estimate the aggregate global impact of local behaviors, those behaviors must themselves be modeled, taking into account how diverse actors respond to local conditions.

The need to reconcile contrasting scales and resolutions results partly from evidentiary constraints, and partly from contrasting foci and explanatory mechanisms of archaeology on 
the one hand and paleoclimatic and paleoenvironmental science on the other. Paleoclimatic and paleoenvironmental science often strives to achieve regional and long-term relevance, resulting in coarser (regional and centennial) scales of analysis. In contrast, archaeological explanation relies fundamentally on anthropological models of behavior - i.e., understandings of human activity that are grounded in decision-making at local and annual scales. As a result, linking analyses that focus on distinct scales, with varying resolutions, is vital to relating archaeological and paleoclimatic and paleoenvironmental data, and has been the focus of both practical and theoretical consideration in archaeology (e.g., Stein, 1993; Lock and Molyneaux, 2006; Robb and Pauketat, 2013; Kintigh and Ingram, 2018). Nevertheless, analysis (and even description) of human-environment interaction remains difficult at best with coarse-grained data, and must confront basic questions of scale and resolution: In space, what do regional-scale data mean for landscape-scale experience, and in time, what do centennial-scale data mean for annual or seasonal experience?

This problem is endemic to applications of regional modeling to archaeological explanation (cf. Brayshaw et al., 2011, p. 28): even when they succeed in revealing interesting patterning, coarse-grained models can suggest broad correlations but require finer-grained analyses if explanatory linking mechanisms are to be pursued. High-resolution empirical data might be ideal, but it is (given the character of paleoclimatic, paleoenvironmental, and archaeological archives) rare and spatially and temporally uneven. In their absence, when only a limited number of observations for a broad area with varied topography may be available from recorded and/or modeled data, it is possible to take modern data from that area and, presuming the climate-geography relationships to have remained relatively constant over time, reconstruct realistically spatially variable climate data. Similarly, modern (recorded) interannual variability can serve as the basis for realistically modeling temporal variability in climate variables. Spatial and temporal downscaling thus offer a way of taking advantage of uneven data to explore potential linking mechanisms between climate variables and human behavior, and ultimately to develop arguments that move from correlation to explanation.

\subsection{Downscaling}

Downscaling addresses the problem of deriving small-scale values from large-scale aggregates (Bierkens et al., 2000, pp. 111-118; Wilby et al., 2004; Wu and Li, 2006, pp. 3436). The principle is that any summary value is by its definition a product of a number of possible individual values that even when not precisely known can be probabilistically estimated. We focus here on statistical downscaling of low-resolution climatic data to enable generation of climate variables at the landscape scale. This is based on applying relationships between high-resolution and low-resolution fields, calibrated based on time periods where both exist, to the target low-resolution field.

The climate-modeling community has explored downscaling of climate data, stimulated by the desire to address regional impacts of climate change in scenarios where global climate models (GCMs) are the primary data source (cf. Fowler et al., 2007; Wilby et al., 2004). The focus has primarily been on future impacts, but the paleoclimate community (e.g., Korhonen et al., 2014; Levavasseur et al., 2011; Vrac et al., 2007) has also begun to explore the potential of downscaling methods as means of examining regional or implications of global models of past climate. Geographically-based downscaling (e.g., Joly et al., 2010; Martin et al., 2013; Vrac et al., 2007) is one means of dealing with spatially heterogeneous landscapes, and is particularly valuable for applications to past climates, as geographic variables are generally stable over archaeological timescales, whereas regional climate relationships to GCMs may have been significantly different in the past (cf. Vrac et al., 2007, p. 670). 
Geographically-based methods which have been applied to paleoclimatological data are based on the calibration of potentially non-linear relationships between the target highresolution variable and its low-resolution version completed by high-resolution geographical variables (topography, distance to sea, etc.; see Vrac et al., 2007). The most appropriate calibration technique is generally recognized to be a generalized additive model (GAM) (Hastie and Tibshirani, 1990) or a multinominial logistic GAM when the variable to interpolate is categorical (Levavasseur et al., 2011, 2013), but other geostatistical methods have also been explored (e.g., Joly et al., 2010; Martin et al., 2013). With fewer potential predictors available at higher spatial resolution and for the past, we have used simple regression to select predictor variables (described in Section 3.2.1, below).

\subsection{Downscaling for Archaeology - Potentials and Limitations}

Archaeologists, given their field's long interest in human-environment interactions, are often avid consumers of paleoclimate data. However, the potential of downscaling has been largely neglected (with important recent exceptions; see Burke et al., 2014; Gauthier, 2016). When downscaling has been explored the target scales have, following the climate work, been regional (with the notable recent exception of Bocinsky and Kohler, 2014).

Spatial and temporal downscaling produces values for climate variables that, for any given pixel in any given year, are in all probability inaccurate: they are single realizations and not unique solutions. However, in aggregate the fidelity to the areal and temporal means represented by the input paleoclimate data is high, and is based on the reasonable assumptions that 1) modern relationships between climate and geographic variables applied also in the past, and 2) $20^{\text {th }}$ century interannual variability resembles past interannual variability. While the second assumption in particular may be questionable, in the absence of a local annuallyresolved paleoclimate archive a better model for interannual variability is unavailable.

As in any modeling exercise, the data employed might also be critiqued. The spatial and temporal downscaling approach presented here can be applied to virtually any input data, but the accuracy of the results is wholly dependent on the accuracy of those data.

Comparisons across space and time within the same dataset, however, can minimize the problem of absolute accuracy of results, and in principle one might also vary the input data if multiple sources were available.

As archaeologists are commonly consumers of paleoclimate data, the archaeological use of climate data - whether from GCMs or derived (as in our case study below) from paleoclimatic reconstructions - is likely to be offline (using previously generated results) rather than coupled to runs of global and/or regional models. Inasmuch as that is the case, archaeologists are more likely to employ statistical downscaling than dynamical downscaling (cf. Fowler et al., 2007, pp. 1548-1552). Although the latter - coupled models able to both incorporate and enable investigation of feedbacks between human activity and climate dynamics - perhaps have the most analytical promise (cf. Wilby et al., 2004, p. 11 on humanclimate feedbacks for contemporary and future models and Kaplan et al., 2010 on the significance of past human activity for regional and global climate), they are also the most complex conceptually and computationally. We address here the less optimal but nevertheless vital statistical downscaling of pre-existing climate data, which represents the more likely scenario for most archaeological practitioners and still promises to enhance archaeological interpretation of the local consequences of past climates.

Even offline, working with extant paleoclimate data/reconstructions, spatial and temporal downscaling has significant potential to enable analytical consideration of humanenvironment interactions at the scale and resolution necessary to consider the human consequences of climate change. Box's dictum that "all models are wrong" (Box, 1979) is 
apropos, and we argue that a downscaling approach produces data that are more useful in archaeological interpretation, and less misleading, than implicit models that posit uniform climate over a large area and over long timespans. It is important to emphasize that using paleoclimate data in archaeological interpretations without downscaling is also an exercise in modeling: it posits a direct one-to-one relationship between local and annual climates and spatially and temporally averaged regional climate data. That being the case, we suggest that consideration of the implications virtually any method of downscaling is likely to improve archaeological interpretation.

The human experience of climate is fundamentally local and annual (if not in fact seasonal), and the consequences of changes in climate are quotidian even if they are measured in aggregate. While the use of global or regional paleoclimate data that is rarely sub-decadal (and often much coarser) reflects the reality of data availability for most archaeological research, a downscaling approach makes it possible to explicitly consider the local and annual implications of such data. This can also provide the requisite spatially explicit and quantitative basis for further modeling that addresses particular questions about the human past, especially past human-environment interactions, including agricultural niche modeling (e.g., Bocinsky and Kohler, 2014; d'Alpoim Guedes et al., 2016), agroecosystem modeling (e.g., Contreras et al., in press), agent-based modeling of subsistence activity (e.g., Barton et al., 2010; Kohler et al., 2012), and isoscape modeling (e.g., Kootker et al., 2016; Willmes et al., 2018). The higher resolution produced by downscaling can enable models suited to construction of more robust arguments about the implications of past environmental change for human experience.

Preindustrial agriculture is a likely mechanism linking changing climates to socioeconomic change (Currie et al., 2015; Schwindt et al., 2016), making the relationship of settlement distributions to climate variables a potential means of examining human ecodynamics. Archaeologists have attempted to reconstruct past ecodynamics by, for example, comparing archaeological settlement patterns against spatial patterning of modern maize productivity in Central Mexico (Gorenflo and Gale, 1986) or against potato and maize productivity in the Central Andes (Seltzer and Hastorf, 1990). More recent efforts have involved sophisticated digital modeling of precipitation-limited maize agriculture in the U.S. Southwest (Bocinsky and Kohler, 2014) or temperature-limited cereal agriculture on the Tibetan Plateau (d'Alpoim Guedes et al., 2016). Questions of scale and resolution are critical to the employment of these models, as topographic and climatic diversity can combine to create viable niches within larger areas that are apparently unsuitable. As the example of the Central Andes demonstrates, the potential exploitation (as well as creation and management, cf. (Erickson, 2000; Mamani Pati et al., 2011)) of microclimates as agricultural niches suggests the importance of fine-grained analysis and consideration of the potential plasticity of thresholds.

A fourth dimension of variability can also be critical: both interannual variability and change over time can be vital parameters for inhabitants. Temporal downscaling enables some consideration of interannual variability, potentially vital in areas where long-term means are poor summaries of annual experience (e.g., where interannual variability is high). In areas where agricultural or foraged resources are near biological thermal or hydrologic limits (or even economic ones), long-term means may be poor indicators of subsistence viability, as periodic low minima may be an unacceptable risk. Re-aggregration of climate data over various timespans can also enable direct comparison of one archaeological period to another, for instance across archaeologically significant thresholds.

\section{Applying Downscaling in Archaeology: A Case Study in Holocene Provence (France)}


We illustrate the data requirements, spatial and temporal downscaling methods, and interpretive payoffs with an example from Holocene Provence.

\subsection{Data}

We present here a computational approach that uses modern $\left(20^{\text {th }}-21^{\text {st }}\right.$ century $)$ CNRM2014 ${ }^{1}$ and CRU TS v. $3.23^{2}$ climate data to relate climatic variables (temperature, precipitation, and cloudiness) to geographic variables (primarily elevation and distance-fromthe-sea $^{3}$ ) through geographically-weighted regression. As the geographic variables are of high spatial resolution where the climate variables are coarse (even for modern data), this relationship can then be used to predict values of climate variables at high spatial resolution.

The problem of temporal resolution is in turn addressed by generating interannual variability within reconstructed trends based on the estimated past seasonal amplitudes and the interannual variability of the modern data. For case study region in Provence that we use here (a topographically diverse $40 \mathrm{~km} \mathrm{x} 40 \mathrm{~km}$ area; see Figure 1), Guiot and Kaniewski's (2015) Holocene climate reconstruction (HolCR) based on inverse vegetation modeling with data from 295 pollen cores provides monthly reconstructions of average daily temperature (ADT), total monthly precipitation (TMP), and \% cloudiness (CLD) (see Figure 2). These monthly values for temperature, precipitation, and \% cloudiness are provided at centennial steps throughout the Holocene ${ }^{4}$, but the $2^{\circ}$ (latitude) by $4^{\circ}$ (longitude) spatial resolution (approximately $225 \times 450 \mathrm{~km}$ cells at Mediterranean latitudes) means that for the study area we use here only a single value for each variable is available. Modern data are higher resolution: for average daily temperature (TAV) and average daily precipitation (PAV) data are available on an 8km grid from the CNRM2014 simulation for the period 1951-2005, while cloudiness (CLD) data is available for the period 1951-2010 at 10' resolution (approximately $18 \mathrm{~km}$ at the latitude of the study area) from the CRU model. Calculating mean TAV and cumulative PAV for each month is necessary to relate the CRNM2014 and HolCR data.

The data sources and their spatial and temporal resolutions are summarized in Table 2.

\subsection{Methodology: A spatial and temporal downscaling approach}

We downscale in two dimensions, addressing both spatial and temporal scales. Following the hierarchical typology established by Bierkens and colleagues (2000, pp. 111144), these comprise distinct problems.

For spatial downscaling, the modern geographic and climate data described above are used to calculate relationships of geographic variables to climate variables at data points known from modern data through geographically weighted linear regression using the spgwr package (Bivand and $\mathrm{Yu}, 2015$ ) in $\mathrm{R}$ (R Core Team, 2016). All raster processing is also carried out in R, using the raster package (Hijmans and van Etten, 2016) in R.

\footnotetext{
${ }^{1}$ A simulation model based on instrumental data, described at http://www.cnrm.meteo.fr/spip.php?article125 and available from the DRIAS Portal: http://www.drias-climat.fr/

${ }^{2}$ Global coverage climate data at $0.5^{\circ}$ resolution from 1901-2014, described in (Harris et al., 2014; New et al., 2002), and available at https://5 data.uea.ac.uk/cru/data/hrg/cru_ts_3.23/cruts.1506241137.v3.23/

${ }^{3}$ Derived from the SRTM 30m digital elevation model (DEM) (NASA JPL, 2013). As detailed below, more environmental variables could in principle be included. In fact, for the case study, for each month and each climatic variable multiple environmental variables were tested and those with the strongest predictive value used (see Table 1).

${ }^{4}$ Available in the OT-Med data catalog at http://database.otmed.fr/geonetworkotmed/srv/eng/search 54b9bf34-57ae-45ea-b455-9f90351e538f
} 
For temporal downscaling, the mean, trend, seasonal, and interannual values from modern data for the study area are used to generate monthly values with a modified version of the greenbrown package (Forkel et al., 2013; Forkel and Wutzler, 2015) in R.

$\mathrm{R}$ code for the procedures detailed below, with reference to the data sources described in Section 3.1 and Table 2, is available in the supplementary online material.

\subsubsection{Spatial downscaling}

The spatial downscaling that we develop here empirically relates fine-scale auxiliary information to the coarse-grained data available to derive a deterministic model. Geographically-weighted regression of modern climate and geographic time-series data is used to establish functions that relate auxiliary information (geographic characteristics) to coarse-grained paleoclimate data (temperature, precipitation, and cloudiness). As even for past time periods geographic data are available at high resolution, they can be used to derive high-resolution climate variables from the existing low-resolution paleoclimate data.

The spatial downscaling procedure, with the input of spatially homogenous data, produces a set of spatial relationships between location and climate variables that can be used to calculate spatially variable rasters of climate variables at temporal resolution that matches the input data. In our case study, this makes possible high-spatial-resolution climate data at centennial steps throughout the Holocene (following the resolution of Guiot and Kaniewski's dataset).

Using a DEM larger than the study area $\left(\sim 3100 \mathrm{~km}^{2}\right.$ rather than $\left.\sim 1400 \mathrm{~km}^{2}\right)$, in order to increase the sample of CNRM2014 points, relationships of geographic variables to climate variables at each point are calculated by geographically weighted linear regression. After extracting values from the rasters of the geographic variables at each point where there are CNRM2014 values for climate variables, regressions are calculated to test the value of various geographic variables as predictors of climate variables, and then to estimate the climatic variables using the values of the selected geographic variables.

Geographic variables that are the strongest predictors for our case study (determined by linear regression using the entire dataset of 54 climate datapoints in the $\sim 3100 \mathrm{~km}^{2}$ area) are elevation and distance from the sea. Irradiance - calculated in GRASS GIS (GRASS Development Team, 2016) with r.sun.daily - and latitude were also tested; neither is a significant predictor, likely as the CNRM2014 data are too spatially sparse to correlate with highly locally-variant environmental characteristics such as irradiance, aspect, topographic roughness, etc. Modern climate data of higher spatial-resolution would allow incorporation of more predictive variables, but even with only two predictor variables that the predictive values are fairly high: mean $\mathrm{R}^{2}$ values (across all months) are .93 for temperature, .80 for precipitation, and .77 for cloudiness. These regressions, in other words, can predict climate variables at an $8 \mathrm{~km}$ resolution with a reasonable degree of confidence, and can thus be used to predict values of climate variables on the basis of geographic variables at finer spatial resolutions - i.e., limited in spatial resolution by the latter but not the former.

The selected geographic variables are then used in a geographically-weighted regression to predict values of climate variables for each cell in a $300 \mathrm{~m}$ pixel raster (spatial resolution could be increased to the limits [30m] of the original DEM with a concomitant increase in computing time ${ }^{5}$ ). For months and/or climate variables when linear regression indicates that distance from the sea is not a significant predictor, elevation alone is used (see Table 1).

\footnotetext{
${ }^{5}$ The target resolution - here $300 \mathrm{~m}$ - depends on analytic needs and practical concerns about computing time and subsequent data management.
} 
For each cell the value of the target climate variable is predicted based on the specified geographic variables, taking into account all points for which both values are available within a specified search radius. Geographically weighted regression (gwr) works to limit the smoothing of spatial variation in the data by "moving a weighted window over the data, estimating one set of coefficient values at every chosen 'fit' point." (Bivand, 2015); that is, relationships between geographic and climate variables can vary locally rather than being based necessarily on a regression across the entire dataset. In the case study here the difference between gwr and other methods is not large, but with denser data or a more spatially variable dataset gwr would in principle be preferable, as it would mirror, rather than smoothing, spatial heterogeneity in the input data.

The resulting raster is cropped to the study area. Following this method a raster is produced for each month for each climate variable. The rasters produced by this process $300 \mathrm{~m}$ resolution, for each month - serve as reference datasets that can be adjusted according to paleoclimate data, producing high spatial-resolution estimates of paleoclimatic conditions.

\subsubsection{Temporal downscaling}

Temporal downscaling, as we employ it here, is a distinct procedure because it must operate without fine-scale auxiliary information, using a mechanistic model and conditionally stochastic methods. These comprise harmonic models with parameters derived from modern interannual variability and the long-term trends and seasonal amplitudes in the coarse-grained data. These are used to generate time-series that constitutes single realizations of the possible solutions within the parameters for the temporal scale. The result - the generation of monthly values that are consistent with the coarse-grained averages though individual values are not directly empirically derived - requires consideration of long-term trends, seasonal amplitudes, and interannual variability.

Centennial means of climate variables for the study area throughout the Holocene are calculated from HolCR and modern reference values for the area calculated from CNRM2014 and CRU data. Centennial trends are provided by linear interpolation from the HolCR data; any three values from HolCR thus produce a continuous 200 -year series, while the varying annual means of the HolCR data capture the longer-term Holocene trends. Seasonal amplitudes are calculated from HolCR by linearly interpolating the monthly values from each centennial step and fitting two-term harmonics to each decade. Temperature, precipitation, and cloudiness are calculated independently from one another. Although in principle these variables are likely to be coupled, modeling those complex and dynamic relationships (the region is influenced by both Atlantic and Mediterranean climate systems) would itself be a considerable task (Fowler et al., 2007, p. 1563). We have not attempted to model these couplings, but the covariance of these variables with the predictors should limit their divergence except in rare (stochastic) cases.

These trend and seasonal components are combined with interannual variability calculated from CNRM2014 and CRU data. For CNRM2014 standard deviation and range of ADT and TMP are calculated from TAV and PAV for the area from $1951-2005$, and for CRU standard deviation and range of cloudiness values are calculated from the data for 1961 - 1990 by subtracting the CRU 'cld' values from 100. Interannual variability throughout the Holocene apparently did not always match modern magnitudes in the region (cf. Büntgen et al., 2011; Luterbacher et al., 2006), but in the absence of specific proxy data of resolution sufficient to reconstruct interannual variability we use modern data.

The mean, trend, seasonal, and interannual values for the study area are used to generate monthly values for a selected time period. The SimTs () function from the greenbrown package generates monthly values for each climate variable for each year of the specified period by building a time series from multiple time-series components: the mean of the time series, the trend slope, the standard deviation of annual means, the range of annual 
means, the seasonal amplitude, and randomly-generated short-term intra-annual variation. The sum of these components describes a time series for the selected variable (cf. Forkel et al., 2013, pp. 2118-2122). In order to fit the seasonal patterns in climate variables in the study area, we replace the cosine harmonic that $\operatorname{SimTs}()$ uses to generate a seasonal distribution with harmonics fitted to the HolCR values for the period as described above.

The modified SimTs ( ) results are monthly values over a 200-year segment, from which the target segment can be extracted if it is shorter. The monthly values for ADT, TMP, and $\%$ cloudiness for that segment are used to calculate monthly anomalies from the HolCR reference values, and new rasters are calculated from the reference rasters by adjusting temperature (average daily temperature in ${ }^{\circ} \mathrm{C}$ ), precipitation (total monthly precipitation in $\mathrm{mm}$ ), and cloudiness (\% cloudcover) using the monthly anomalies for each year of the selected time window.

As a period of interest is defined and the data for those dates extracted from the Guiot and Kaniewski (2015) dataset, anomalies from the modern data are calculated, and the reference rasters can be used to derive rasters at 300m-resolution for any year of the Holocene for the three climate variables, all by month. To capture the trend in annual means and seasonal amplitude across a target window 200 years of data (three datapoints) are the minimum to work with. Using these in the temporal downscaling process, a time-series of spatially-downscaled rasters can be generated, from which a smaller segment can subsequently be extracted.

\section{Results: From Centennial Means to a Year in Provence}

Mediterranean climate variation during the Holocene is modest compared to that of the Pleistocene, but nonetheless paleoclimate data underpins a large number of studies positing relationships between climate changes and cultural developments (see partial reviews in Finné et al., 2011; Roberts et al., 2004; Robinson et al., 2006). This is particularly true in the eastern Mediterranean (e.g., Kaniewski et al., 2015; Weninger et al., 2009; Wiener, 2014), reflecting greater abundance of archaeological and paleoclimatic research, but Holocene climate-culture links have also been suggested in the western Mediterranean (e.g., Berger and Guilaine, 2009; Carozza et al., 2015; Weinelt et al., 2015). As discussed above, the elucidation of these links is limited by chronological resolution and the often incommensurate scales of analysis and explanation pursued by paleoclimatologists and archaeologists.

In the Mediterranean, the diversity of microenvironments characteristic of such a topographically complex region historically has significantly complicated generalization from paleoclimate data, and further complicates the exploration of the human consequences of climate change. In Provence, geographic variability is one of the principle drivers of the region's significant environmental diversity (cf. Blondel and colleagues [2010, p. 13], who single out, "slope, exposition, distance from the sea, steepness, and parent rock type"). Although of course other variables (e.g., water availability, soil depth, etc.) are also influential, environmental contrasts apparent over short distances reflect in large part the interaction of topographic variability and climatic variability. Climate changes may thus affect the spatial distribution of environmental variability as well as the environment in aggregate; both can impact the human inhabitants of a landscape. Interannual variability, which can be obscured by long-term means, may also be particularly significant for inhabitants.

Employing a spatial and temporal downscaling approach to explore the human consequences of past climate changes at large spatial scale and high temporal resolution to a Mediterranean case provides a means of addressing the challenges of a) reconciling scales and 
case study area in Provence explores this across an approximately $1400 \mathrm{~km}^{2}$ study area

433 (Figure 1) that spans significant topographic variability: elevations range between 50 and

4341200 masl and the area includes both the floodplain of the Durance River and the steep limestone ridge of the Luberon. For the period for which instrumental data are available (or modeled data based directly on instrumental data; namely the CNRM2014 and CRU datasets), average daily temperatures (TAV) vary in space by $4-5{ }^{\circ} \mathrm{C}$ in each month of the year, and total monthly precipitation (TMP) by $12-32 \mathrm{~mm}$ (see Figure 3 ). Long-term temporal variation, by comparison, assessed from the HolCR dataset across the entire Holocene for the cell including the study area, is generally more modest: AMT has varied by approximately 1$2.5^{\circ} \mathrm{C}$, depending on the month, and TMP has ranged by $10-20 \mathrm{~mm}$, depending on the month (see Figure 4).

The combination of spatial and interannual variability produces marked contrasts across the study area, belying the homogeneity fundamental to a coarse-grained reconstruction. Downscaling of AMT in the study area at $2400 \mathrm{BP}$ - the coolest period of the Holocene - for instance, demonstrates both the strong seasonality recorded in the input data and the spatial variability in temperature produced by elevation gradients that is absent in the input data but produced by the downscaling process (Figure 5). AMT values from the HolCR dataset for $2400 \mathrm{BP}$ range from 3.1 to $21.6^{\circ} \mathrm{C}$, while the downscaled rasters display lower minima and higher maxima, reflecting spatially variable values for each month (Table 3 ).

The addition of temporal downscaling makes it possible to move from spatiallyvariable but static climate reconstructions to time-series of spatially-variable reconstructions that better reflect the variable and dynamic environments that inhabitants of the region would have experienced. The addition of temporal variability following centennial trends is illustrated in Figure 6, while Figure 7 demonstrates the results of temporal downscaling to generate variability following centennial trends and modern interannual variability, in this case precipitation in the month of March for the period 4004 BP - $3096 \mathrm{BP}$, the driest period of the Holocene. Where HolCR provided a single TMP value of $36.2 \mathrm{~mm}$ and spatial downscaling produced a spatial range of $25.2-69.2 \mathrm{~mm}$ (Figure 7a), temporal downscaling to generate interannual variability produced a sequence of rasters whose minima range from 0 $-33.9 \mathrm{~mm}$ and whose maxima range from $27.5-77.8 \mathrm{~mm}$ (Figure $7 \mathrm{~b}$; this is a single realization illustrating one possible solution).

These downscaled data open new analytical possibilities, particularly regarding human-environment interactions and potential impacts of climate change. Variability of the magnitude and at the spatial and temporal scales visible in Figure $7 \mathrm{~b}$ can be vital to archaeological interpretation, and downscaling enables consideration, for instance, of whether site distributions are random with respect to climate variables. Various other factors notably chronological resolution, landscape taphonomy, and recovery bias - make assessment of settlement pattern data in the study area an analytical challenge, but even with such challenges downscaled paleoclimate data have the potential to generate hypotheses that would have otherwise remained inaccessible.

The Late Iron Age expansion of settlement in the study area illustrated in Figure 8, for example, might represent a simple infilling of the landscape as population increased (push factors: local population increase, political and/or economic imperatives, etc.), and/or it might represent the results of the opening up of previously unused areas (pull factors: changes in agricultural practices or technologies [irrigation, iron plowshares, etc.)], shifts in crop preference, willingness to accept less productive land, changes in climate, etc.). Downscaled climate data make it possible to evaluate the hypothesis that changing climate enabled agricultural expansion into areas previous insufficiently productive to be exploited: comparison of the quantities and variability of precipitation in the areas settled (Figure 8) suggest little change from the Early to Late Iron Age, and the summarized values around each 
settlement do not show any strong contrast from one period to the next (see boxplots at left in Figure 8; the climate-driven contrast in standard deviations is clearly statistically significant, but the magnitude of difference [a decline of $2 \%$ in TMP] is probably too low to suggest any notable shift in agricultural potential).

Higher-resolution cultural chronology, as well as specific consideration of the hydrologic needs of particular crops, might enable further evaluation of climate impacts in the $3^{\text {rd }}$ millennium BP. For that or any other period, resolution of the cultural chronology is a limiting factor in interpreting any effects of climate change: although the downscaled data enable tracking changing spatial patterns of climate variability, the settlement data do not always allow tracking of changes in settlement patterns at comparable temporal resolution, and aggregation of the climate data over archaeological periods (each of approximately four centuries here) may efface important variability. However, this evidence of broad consistency in climatic conditions and niches exploited suggests that climate was not a strong driver of settlement pattern in the study area during this period (and moreover the apparent sudden increase in site density in the Late Iron Age is in fact an artifact of time-averaging and was rather the result of gradual growth (cf. Isoardi, 2010)). Such (preliminary) negative evidence only becomes possible with downscaled data; with only coarse-grained data like that in Figure $7 \mathrm{a}$, questions like these, vital to considering potential impacts of past climate changes, cannot even be asked.

\section{Conclusions}

The simulated data produced by spatial and temporal downscaling capture both spatial variability and interannual variation in climatic factors, parameters fundamental to assessing the human consequences of climate changes. Examining such consequences at high resolution is necessary to analysis of the significance of climatic factors for such fundamental human activities as agriculture, and thus vital to the articulation of mechanisms linking climate and cultural change. There are drawbacks: downscaling adds a further layer of analysis, and can create a seductive precision when in fact it produces non-unique solutions that should be understand as reasonable but not necessarily accurate. However, not downscaling is also dangerous: it represents an implicit downscaling, in which coarse-grained data are presumed to indicate homogeneity within each granule, and understood as relevant at scales finer than those measured but without explicit mechanisms to relate regional to local or time-averaged to temporally-variable.

The methodology that we have presented here is straightforward to apply for any portion of the Holocene anywhere in the Mediterranean Basin using the same datasets, and the approach is adaptable to other regions and input data. The value of such data manipulation is analogous to what Lake $(2015$, p. 9) describes with reference to archaeological simulation modeling: it enables the virtual disaggregation of spatially and temporally coarse-grained data, and thus constitutes an important tool in shifting to a human scale of analysis. It can provide the raw material for further modeling and analysis focused on socioecological systems (advocated as a unique and significant contribution of archaeology to studies of sustainability and resilience; cf. Barton et al., 2012; Kohler and van der Leeuw, 2007; Van der Leeuw et al., 2011). Such modeling often requires higherresolution and larger-scale data than that generally available from paleoclimate archives; indeed one of the benefits of such models is that they mandate explicit consideration of data requirements. The problem is not uniquely archaeological: developing agent-based models, agroecosystem models, or erosion models at scales directly relatable to human experience and decision-making is as much a challenge for socioecological science of the present as of the past. Downscaling tools are thus as needed in present-day modeling as in archaeological 
simulation, and are vital for considering, for instance, the specific implications at local scales - i.e., the human impacts - of the $1.5-2{ }^{\circ} \mathrm{C}$ of global warming targeted by the COP 21 agreement. Methodologies like that presented here thus add needed components to the analytical toolkit for past human-environment dynamics, and potentially contribute to exploration of present and future human-environment dynamics as well.

\section{List of Figures}

Figure 1: Area of the case study.

541 Figure 2: Annual means (calculated from monthly values) of Holocene temperature (ADT) and precipitation (TMP) for the study area in centennial steps, from the HolCR dataset (Guiot and Kaniewski 2015) adjusted by using CNRM2014 data as a modern reference. Data on \% cloudiness is also included, but not plotted here.

Figure 3: Mean values (ADT and TMP) of each of the 24 CNRM2014 datapoints within the study area for all points within the study area for the period 1950-2005 - i.e., the spatial variability in temperature and precipitation over a 56-year span. Labels denote the range of variability for each month.

Figure 4: Diachronic variability in ADT and TMP in the HolCR dataset for the cell including the study area, throughout the Holocene (data centered but not scaled).

Figure 5: Spatially downscaled monthly rasters for $2400 \mathrm{BP}$, the coolest period of the Holocene, with 100m contours derived from the SRTM30 DEM.

Figure 6: Temporally downscaled annual means of temperature (ADT) and precipitation (TMP) for the period 4200-4000 BP in the study area, with HolCR datapoints (solid circles) for reference. Inter-annual variability is based on the range and standard deviation of modern (CNRM2014) data, and the means and trends of the time series provided by the HolCR values (see Section 3.2.2).

Figure 7: a) Example of HolCR data for October 4000 BP, with CNRM2014 datapoints (black circles) and 100m elevation contours derived from the SRTM30 DEM. The source data provides monthly values like this in centennial steps. b) After spatial downscaling, values for March 4000 BP (middle panel) are spatially variable, and can be temporally downscaled for intervening years following centennial trends and modern interannual variability (e.g., illustrated in the nine panels here, the month of March for 4004 BP - 3096 BP).

Figure 8: Early (green diamonds) and newly established Late (red triangles) Iron Age occupation and agricultural sites, plotted on $300 \mathrm{~m}$ raster of mean annual TMP and standard deviation in TMP for the Early Iron Age and Late Iron Age (approximately 2700-2400 and 2400-2002 BP, respectively). Boxplots indicate precipitation niches occupied by occupation and agricultural sites in the Early and Late Iron Age: each datapoint represents the mean TMP over the period within a $200 \mathrm{~m}$ buffer around a site.

\section{List of Tables}

Table 1: Geographic variables and their predictive utility in the spatial downscaling process. Table 2: Data sources.

Table 3: Monthly temperatures from HolCR and downscaling results for the study area at $2400 \mathrm{BP}$.

\section{Acknowledgements}

Research has been funded by Labex OT-Med (ANR-11-LABEX-0061), the AMEDEES project, supported by A*MIDEX project 11-IDEX-0001-02, "Investissements d'Avenir" 
French Government project of the French National Research Agency (ANR) and by ECCOREV (AMEDEES-DB project). We thank the other members of the AMENOPHYS and AMEDEES projects, particularly Alberte Bondeau, Loup Bernard, Eneko Hiriart, Nobi Hanaki, and Sylvie Thoron. The paper has been considerably improved thanks to the thoughtful and constructive comments of two anonymous reviewers. The archaeological data in Figure 8, from the Patriarche database (http://www.culturecommunication.gouv.fr/Politiques-ministerielles/Archeologie/Etuderecherche/Carte-archeologique-nationale), were kindly provided by the Ministère de la Culture et de la Communication (DRAC PACA/SRA).

590

591

592

593

594

595

596

597

598

599

600

601

602

603

604

605

606

607

608

609

610

611

612

613

614

615

616

617

618

619

620

621

622

623

624

625

\section{$\underline{\text { References cited }}$}

Barton, C.M., Ullah, I., Bergin, S.M., Mitasova, H., Sarjoughian, H., 2012. Looking for the future in the past: Long-term change in socioecological systems. Ecological Modelling 241, 42-53.

Barton, C.M., Ullah, I.I., Bergin, S., 2010. Land use, water and Mediterranean landscapes: modelling long-term dynamics of complex socio-ecological systems. Philosophical Transactions of the Royal Society A: Mathematical, Physical and Engineering Sciences 368, 5275-5297. https://doi.org/10.1098/rsta.2010.0193

Berger, J.-F., Guilaine, J., 2009. The 8200 cal BP abrupt environmental change and the Neolithic transition: A Mediterranean perspective. Quaternary International 200, 31-49.

Bierkens, M., Finke, P., De Willigen, P., 2000. Upscaling and downscaling methods for environmental research. Kluwer Academic, Dordrecht.

Bivand, R., Yu, D., 2015. spgwr: Geographically Weighted Regression.

Bivand, R.S., 2015. Geographically Weighted Regression [WWW Document]. URL https://cran.r-project.org/web/packages/spgwr/vignettes/GWR.pdf

Blondel, J., Aronson, J., Bodiou, J.Y., Boeuf, G., 2010. The Mediterranean region: biological diversity in space and time, 2nd ed. Oxford University Press, Oxford.

Bocinsky, R.K., Kohler, T.A., 2014. A 2,000-year reconstruction of the rain-fed maize agricultural niche in the US Southwest. Nature Communications 5, 5618.

Box, G.E., 1979. Robustness in the strategy of scientific model building, in: Launer, R.L., Wilkinson, G.N. (Eds.), Robustness in Statistics. Academic Press, New York, pp. 201-236.

Braje, T.J., 2015. Earth systems, human agency, and the Anthropocene: Planet Earth in the human age. Journal of Archaeological Research 23, 369-396.

Brayshaw, D.J., Rambeau, C.M., Smith, S.J., 2011. Changes in Mediterranean climate during the Holocene: Insights from global and regional climate modelling. The Holocene $21,15-31$.

Büntgen, U., Tegel, W., Nicolussi, K., McCormick, M., Frank, D., Trouet, V., Kaplan, J.O., Herzig, F., Heussner, K.U., Wanner, H., Luterbacher, J., Esper, J., 2011. 2500 Years of European Climate Variability and Human Susceptibility. Science 331, 578-582.

Burke, A., Levavasseur, G., James, P.M.A., Guiducci, D., Izquierdo, M.A., Bourgeon, L., Kageyama, M., Ramstein, G., Vrac, M., 2014. Exploring the impact of climate variability during the Last Glacial Maximum on the pattern of human occupation of Iberia. Journal 
of Human Evolution 73, 35-46.

627 Carozza, L., Berger, J.-F., Burens, A., Marcigny, C., 2015. Society and environment in

628 Southern France from the 3rd millennium BC to the beginning of the 2nd millennium BC:

$6292200 \mathrm{BC}$ a tipping point? Tagungen des Landesmuseums für Vorgestchiche Halle 12,

$630 \quad 333-362$.

631 Contreras, D.A., 2017. Correlation is Not Enough - Building Better Arguments in the

632 Archaeology of Human-Environment Interactions, in: Contreras, D.A. (Ed.), The

633 Archaeology of Human-Environment Interaction: Strategies for Investigating

634 Anthropogenic Landscapes, Dynamic Environments, and Climate Change in the Human

635 Past. Routledge, New York, pp. 3-22.

636 Contreras, D.A., Bondeau, A., Guiot, J., Kirman, A., Hiriart, E., Bernard, L., Suarez, R., Fader,

637 M., in press. From Paleoclimate Variables to Prehistoric Agriculture: Using a Process-

638 Based Agroecosystem Model to Simulate the Impacts of Holocene Climate Change on

639 Potential Prehistoric Agricultural Productivity in Provence, France. Quaternary

640 International.

641 Crutzen, P.J., Steffen, W., 2003. How long have we been in the Anthropocene era?

642 Climatic Change 61, 251-257.

643 Currie, T.E., Bogaard, A., Cesaretti, R., Edwards, N., Francois, P., Holden, P., Hoyer, D., 644 Korotayev, A., Manning, J., Moreno Garcia, J.C., Oyebamiji, O.K., Petrie, C., Turchin, P., Whitehouse, H., Williams, A., 2015. Agricultural productivity in past societies: Toward an empirically informed model for testing cultural evolutionary hypotheses. Cliodynamics

648 d'Alpoim Guedes, J., Manning, S., Bocinsky, R.K., 2016. A 5,500-Year Model of Changing 649 Crop Niches on the Tibetan Plateau. Current Anthropology 57, 1-6.

650 Erickson, C.L., 2000. The Lake Titicaca Basin: A Precolumbian Built Landscape, in: Lentz, 651 D.L. (Ed.), Imperfect Balance: Landscape Transformations in the Precolumbian 652 Americas. Cambridge University Press, New York, pp. 311-356.

653 Erlandson, J.M., Braje, T.J., 2013. Archeology and the Anthropocene. Anthropocene 4, 16547.

655 Finné, M., Holmgren, K., Sundqvist, H.S., Weiberg, E., Lindblom, M., 2011. Climate in the eastern Mediterranean, and adjacent regions, during the past 6000 years - A review.

658 Forkel, M., Carvalhais, N., Verbesselt, J., Mahecha, M.D., Neigh, C.S., Reichstein, M., 2013.

659 Trend change detection in NDVI time series: Effects of inter-annual variability and 660 methodology. Remote Sensing 5, 2113-2144.

661 Forkel, M., Wutzler, T., 2015. greenbrown - land surface phenology and trend analysis. A 662 package for the R software.

663 Fowler, H.J., Blenkinsop, S., Tebaldi, C., 2007. Linking climate change modelling to impacts studies: recent advances in downscaling techniques for hydrological modelling.

International Journal of Climatology 27, 1547-1578.

666 Gauthier, N., 2016. The spatial pattern of climate change during the spread of farming

667 into the Aegean. Journal of Archaeological Science 75, 1-9.

668 Gorenflo, L., Gale, N., 1986. Population and productivity in the Teotihuacan Valley:

669 changing patterns of spatial association in prehispanic central Mexico. Journal of

670 Anthropological Archaeology 5, 199-228. 
671 GRASS Development Team, 2016. Geographic Resources Analysis Support System

672 (GRASS GIS) Software, Version 7.0. Open Source Geospatial Foundation.

673 Guiot, J., Kaniewski, D., 2015. The Mediterranean Basin and Southern Europe in a

674 warmer world: what can we learn from the past? Frontiers in Earth Science 3, 1-16.

675 Harris, I., Jones, P., Osborn, T., Lister, D., 2014. Updated high-resolution grids of monthly 676 climatic observations-the CRU TS3. 10 Dataset. International Journal of Climatology 34, 677 623-642.

678 Hastie, T.J., Tibshirani, R.J., 1990. Generalized Additive Models. Chapman and Hall/CRC, 679 London.

680 Hijmans, R.J., van Etten, J., 2016. raster: Geographic data analysis and modeling.

681 Isoardi, D., 2010. Archéodémographie des sociétés protohistoriques de Sud-Est de la 682 France. Arqueología Espacial 28, 265-284.

683 Joly, D., Brossard, T., Cardot, H., Cavailhes, J., Hilal, M., Wavresky, P., 2010. Temperature 684 interpolation based on local information: the example of France. International Journal of 685 Climatology 31, 2141-2153.

686 Kaniewski, D., Guiot, J., Van Campo, E., 2015. Drought and societal collapse 3200 years 687 ago in the Eastern Mediterranean: a review. Wiley Interdisciplinary Reviews: Climate 688 Change 6, 369-382.

689 Kaplan, J.O., Krumhardt, K.M., Ellis, E.C., Ruddiman, W.F., Lemmen, C., Klein Goldewijk, K., 690 2010. Holocene carbon emissions as a result of anthropogenic land cover change. The 691 Holocene. https://doi.org/10.1177/0959683610386983

692 Kintigh, K.W., Altschul, J.H., Beaudry, M.C., Drennan, R.D., Kinzig, A.P., Kohler, T.A., Limp, 693 W.F., Maschner, H.D.G., Michener, W.K., Pauketat, T.R., Peregrine, P., Sabloff, J.A., 694 Wilkinson, T.J., Wright, H.T., Zeder, M.A., 2014. Grand challenges for archaeology.

695 Proceedings of the National Academy of Sciences 111, 879-880.

696 Kintigh, K.W., Ingram, S.E., 2018. Was the drought really responsible? Assessing 697 statistical relationships between climate extremes and cultural transitions. Journal of 698 Archaeological Science 89, 25-31.

699 Kohler, T.A., Bocinsky, R.K., Cockburn, D., Crabtree, S.A., Varien, M.D., Kolm, K.E., Smith, 700 S., Ortman, S.G., Kobti, Z., 2012. Modelling prehispanic Pueblo societies in their 701 ecosystems. Ecological Modelling 241, 30-41.

702 Kohler, T.A., van der Leeuw, S.E., 2007. The Model-based Archaeology of Socionatural 703 Systems. School for American Research Press, Santa Fe.

704 Kootker, L.M., van Lanen, R.J., Kars, H., Davies, G.R., 2016. Strontium isoscapes in The 705 Netherlands. Spatial variations in $87 \mathrm{Sr} / 86 \mathrm{Sr}$ as a proxy for palaeomobility. Journal of 706 Archaeological Science: Reports 6, 1-13.

707 Korhonen, N., Venäläinen, A., Seppä, H., Järvinen, H., 2014. Statistical downscaling of a 708 climate simulation of the last glacial cycle: temperature and precipitation over Northern 709 Europe. Climate of the Past 10, 1489-1500.

710 Lake, M.W., 2015. Explaining the Past with ABM: On Modelling Philosophy, in: Wurzer, 711 G., Kowarik, K., Reschreiter, H. (Eds.), Agent-Based Modeling and Simulation in 712 Archaeology. Springer, Heidelberg, pp. 3-36.

713 Levavasseur, G., Vrac, M., Roche, D., Paillard, D., Guiot, J., 2013. An objective methodology 714 for potential vegetation reconstruction constrained by climate. Global and Planetary 715 Change 104, 7-22. 
Levavasseur, G., Vrac, M., Roche, D., Paillard, D., Martin, A., Vandenberghe, J., 2011.

717 Present and LGM permafrost from climate simulations: contribution of statistical

718 downscaling. Climate of the Past 7, 1225-1246.

719 Lock, G., Molyneaux, B.L., 2006. Confronting Scale in Archaeology: Issues of Theory and

720 Practice. Springer, New York.

721 Luterbacher, J., Xoplaki, E., Casty, C., Wanner, H., Pauling, A., Küttel, M., Brönnimann, S.,

722 Fischer, E., Fleitmann, D., Gonzalez-Rouco, F.J., others, 2006. Mediterranean climate

723 variability over the last centuries: a review. Developments in Earth and environmental

724 Sciences 4, 27-148.

725 Mamani Pati, F., Clay, D.E., Smeltekop, H., 2011. Geospatial Management of Andean

726 Technology by the Inca Empire, in: Clay, D.E., Shanahan, J.F. (Eds.), GIS Applications in

727 Agriculture, Volume Two: Nutrient Management for Energy Efficiency. CRC Press, Boca

728 Raton, pp. 255-264.

729 Martin, N., Carrega, P., Adnes, C., 2013. Downscaling À Fine Résolution Spatiale des

730 Températures Actuelles et Futures par Modélisation Statistique des Sorties Aladin-

731 Climat sur les Alpes-Maritimes (France). Climatologie 10, 51-74.

732 Morrison, K.D., 2015. Provincializing the Anthropocene. Seminar 673, 75-80.

733 NASA JPL, 2013. NASA Shuttle Radar Topography Mission Global 1 arc second number.

734 New, M., Lister, D., Hulme, M., 2002. A high-resolution data set of surface climate over 735 global land areas. Climate Research 21, 1-25.

736 R Core Team, 2016. R: A Language and Environment for Statistical Computing. R

737 Foundation for Statistical Computing, Vienna, Austria.

738 Robb, J., Pauketat, T.R., 2013. From moments to millennia: Theorizing scale and change

739 in human history, in: Robb, J., Pauketat, T.R. (Eds.), Big Histories, Human Lives: Tackling

740 Problems of Scale in Archaeology. School for Advanced Research Press, Santa Fe, NM, pp. $7413-33$.

742 Roberts, N., Stevenson, T., Davis, B., Cheddadi, R., Brewster, S., Rosen, A., 2004. Holocene 743 climate, environment and cultural change in the circum-Mediterranean region, in:

744 Battarbee, R.W., Gasse, F., Stickley, C.E. (Eds.), Past Climate Variability through Europe

745 and Africa. Springer, Dordrecht, pp. 343-362.

746 Robinson, S.A., Black, S., Sellwood, B.W., Valdes, P.J., 2006. A review of palaeoclimates

747 and palaeoenvironments in the Levant and Eastern Mediterranean from 25,000 to 5000

748 years BP: setting the environmental background for the evolution of human civilisation.

749 Quaternary Science Reviews 25, 1517-1541.

750 https://doi.org/10.1016/j.quascirev.2006.02.006

751 Ruddiman, W.F., 2013. The Anthropocene. Annual Review of Earth and Planetary

752 Sciences 41, 45-68.

753 Schwindt, D.M., Bocinsky, R.K., Ortman, S.G., Glowacki, D.M., Varien, M.D., Kohler, T.A.,

754 2016. The Social Consequences of Climate Change in the Central Mesa Verde Region.

755 American Antiquity 81, 74-96.

756 Seltzer, G.O., Hastorf, C., 1990. Climatic Change and Its Effect on Prehispanic Agriculture

757 in the Central Peruvian Andes. Journal of Field Archaeology 17, 397-414.

758 Smith, B.D., Zeder, M.A., 2013. The onset of the Anthropocene. Anthropocene 4, 8-13.

759 Smith, M.E., Feinman, G.M., Drennan, R.D., Earle, T., Morris, I., 2012. Archaeology as a

760 social science. Proceedings of the National Academy of Sciences 109, 7617-7621. 
Spiridonov, V., Déqué, M., Somot, S., 2005. ALADIN-CLIMATE: from the origins to present date. ALADIN Newsletter 29, 89-92.

Stein, J.K., 1993. Scale in archaeology, geosciences, and geoarchaeology. Geological Society of America Special Papers 283, 1-10.

Van der Leeuw, S., Costanza, R., Aulenbach, S., Brewer, S., Burek, M., Cornell, S., Crumley, C.L., Dearing, J.A., Downy, C., Graumlich, L.J., Heckbert, S., Hegmon, M., Hibbard, K., Jackson, S.T., Kubiszewski, I., Sinclair, P., Sörlin, S., Steffen, W., 2011. Toward an integrated history to guide the future. Ecology and Society 16.

Van der Leeuw, S., Redman, C., 2002. Placing archaeology at the center of socio-natural studies. American Antiquity 67, 597-605.

Vidal, J.-P., Martin, E., Franchistéguy, L., Baillon, M., Soubeyroux, J.-M., 2010. A 50-year high-resolution atmospheric reanalysis over France with the Safran system. International Journal of Climatology 30, 1627-1644.

Vrac, M., Marbaix, P., Paillard, D., Naveau, P., 2007. Non-linear statistical downscaling of present and LGM precipitation and temperatures over Europe. Climate of the Past 3, 669-682.

Weinelt, M., Schwab, C., Kneisel, J., Hinz, M., 2015. Climate and societal change in the western Mediterranean area around 4.2 ka BP, in: Meller, H., Arz, H.W., Jung, R., Risch, R. (Eds.), 2200 BC- A Climatic Breakdown as a Cause for the Collapse of the Old World? Landesmuseum für Vorgeschichte, Halle, pp. 461-480.

Weninger, B., Clare, L., Rohling, E., Bar-Yosef, O., Böhner, U., Budja, M., Bundschuh, M., Feurdean, A., Gebe, H.G., Jöris, O., Linstädter, J., Mayewski, P., Mühlenbruch, T., Reingruber, A., Rollefson, G.O., Schyle, D., Thissen, L., Todorova, H., Zielhofer, C., 2009. The Impact of Rapid Climate Change on Prehistoric Societies during the Holocene in the Eastern Mediterranean. Documenta Praehistorica 36, 7-59.

Wiener, M., 2014. The Interaction of Climate Change and Agency in the Collapse of Civilizations ca. 2300-2000 BC. Radiocarbon 56, S1-S16.

Wilby, R.L., Charles, S.P., Zorita, E., Timbal, B., Whetton, P., Mearns, L.O., 2004. Guidelines for Use of Climate Scenarios Developed from Statistical Downscaling Methods (Supporting Material of the Intergovernmental Panel on Climate Change (IPCC)), Prepared on Behalf of Task Group on Data and Scenario Support for Impacts and Climate Analysis (TGICA). IPCC.

Willmes, M., Bataille, C.P., James, H.F., Moffat, I., McMorrow, L., Kinsley, L., Armstrong, R.A., Eggins, S., Grün, R., 2018. Mapping of bioavailable strontium isotope ratios in France for archaeological provenance studies. Applied Geochemistry 90, 75-86.

Wu, J., Li, H., 2006. Perspectives and Methods of Scaling, in: Wu, J., Jones, K.B., Li, H., Loucks, O.L. (Eds.), Scaling and Uncertainty Analysis in Ecology: Methods and Applications. Springer, Dordrecht, pp. 14-42.

Zalasiewicz, J., Waters, C.N., Williams, M., Barnosky, A.D., Cearreta, A., Crutzen, P., Ellis, E., Ellis, M.A., Fairchild, I.J., Grinevald, J., Haff, P.K., Hajdas, I., Leinfelder, R., McNeill, J., Odada, E.O., Poirier, C., Richter, D., Steffen, W., Summerhayes, C., Syvitski, J.P.M., Vidas, D., Wagreich, M., Wing, S.L., Wolfe, A.P., Zhisheng, A., Oreskes, N., 2015. When did the Anthropocene begin? A mid-twentieth century boundary level is stratigraphically optimal. Quaternary International 383, 196-203. 
Table 1: Data sources.

\begin{tabular}{|c|c|c|c|c|c|}
\hline Data source & Summary description & $\begin{array}{c}\text { Variables } \\
\text { used }\end{array}$ & $\begin{array}{c}\text { Spatial } \\
\text { resolution }\end{array}$ & $\begin{array}{l}\text { Temporal } \\
\text { resolution } \\
\text { and span }\end{array}$ & Reference and data url \\
\hline CNRM2014 & $\begin{array}{l}\text { Simulated dataset based on the } \\
\text { limited-area aladin-Climate model } \\
\text { (Aire Limited Adaptation Dynamic } \\
\text { development InterNational) and } \\
\text { corrected by a quantile-quantile } \\
\text { method to SAFRAN (Vidal et al., } \\
\text { 2010). }\end{array}$ & TAV, PAV & $8 \mathrm{~km}$ & $\begin{array}{l}\text { Monthly } \\
\text { values, 1950- } \\
2005\end{array}$ & $\begin{array}{l}\text { (Spiridonov et al., 2005); } \\
\text { http://www.cnrm.meteo.fr/spip.php?article125; } \\
\text { DRIAS Portal at http://www.drias-climat.fr/ }\end{array}$ \\
\hline CRU & $\begin{array}{l}\text { Global ridded climate dataset } \\
\text { interpolated from } 20^{\text {th }}-21^{\text {st }} \text { century } \\
\text { meteorological station data. }\end{array}$ & $\operatorname{cld}^{\mathrm{a}}$ & $10^{\prime}$ & $1951-2010$ & $\begin{array}{l}\text { (Harris et al., 2014; New et al., 2002); } \\
\text { https://crudata.uea.ac.uk/cru/data/hrg/tmc/ }\end{array}$ \\
\hline HolCR & $\begin{array}{l}\text { Holocene climate reconstruction } \\
\text { based on pollen data and an inverse } \\
\text { vegetation model (BIOME4) }\end{array}$ & $\begin{array}{l}\text { ADT, } \mathrm{TMP} \\
\% \text { cloudiness }\end{array}$ & $\begin{array}{l}2^{\circ} \text { latitude } \\
\times 4^{\circ} \\
\text { longitude }\end{array}$ & $\begin{array}{l}\text { Monthly } \\
\text { estimates in } \\
\text { centennial } \\
\text { steps; } 10000 \\
\text { BP - present }\end{array}$ & $\begin{array}{l}\text { (Guiot and Kaniewski, 2015); OT-Med data catalog at } \\
\text { http://database.otmed.fr/geonetworkotmed/srv/eng/sea } \\
\underline{\text { rch - |54b9bf34-57ae-45ea-b455-9f90351e538f }}\end{array}$ \\
\hline SRTM30 & digital elevation model & elevation $^{b}$ & $30 \mathrm{~m}$ & 2000 & (NASA JPL, 2013); http://dds.cr.usgs.gov/srtm/ \\
\hline
\end{tabular}

a. In fact the CRU dataset provides \% sunniness, which must be subtracted from 100 to provide \% cloudiness.

b. Although they were not ultimately used, we also tested elevation derivatives, e.g., slope, aspect, and irradiance. 
Table 1: Data sources.

\begin{tabular}{|c|c|c|c|c|c|}
\hline Data source & Summary description & $\begin{array}{c}\text { Variables } \\
\text { used }\end{array}$ & $\begin{array}{c}\text { Spatial } \\
\text { resolution }\end{array}$ & $\begin{array}{l}\text { Temporal } \\
\text { resolution } \\
\text { and span }\end{array}$ & Reference and data url \\
\hline CNRM2014 & $\begin{array}{l}\text { Simulated dataset based on the } \\
\text { limited-area aladin-Climate model } \\
\text { (Aire Limited Adaptation Dynamic } \\
\text { development InterNational) and } \\
\text { corrected by a quantile-quantile } \\
\text { method to SAFRAN (Vidal et al., } \\
\text { 2010). }\end{array}$ & TAV, PAV & $8 \mathrm{~km}$ & $\begin{array}{l}\text { Monthly } \\
\text { values, 1950- } \\
2005\end{array}$ & $\begin{array}{l}\text { (Spiridonov et al., 2005); } \\
\text { http://www.cnrm.meteo.fr/spip.php?article125; } \\
\text { DRIAS Portal at http://www.drias-climat.fr/ }\end{array}$ \\
\hline CRU & $\begin{array}{l}\text { Global gridded climate dataset } \\
\text { interpolated from } 20^{\text {th }}-21^{\text {st }} \text { century } \\
\text { meteorological station data. }\end{array}$ & $\operatorname{cld}^{\mathrm{a}}$ & $10^{\prime}$ & $1951-2010$ & $\begin{array}{l}\text { (Harris et al., 2014; New et al., 2002); } \\
\text { https://crudata.uea.ac.uk/cru/data/hrg/tmc/ }\end{array}$ \\
\hline HolCR & $\begin{array}{l}\text { Holocene climate reconstruction } \\
\text { based on pollen data and an inverse } \\
\text { vegetation model (BIOME4) }\end{array}$ & $\begin{array}{l}\text { ADT, } \mathrm{TMP} \\
\% \text { cloudiness }\end{array}$ & $\begin{array}{l}2^{\circ} \text { latitude } \\
\times 4^{\circ} \\
\text { longitude }\end{array}$ & $\begin{array}{l}\text { Monthly } \\
\text { estimates in } \\
\text { centennial } \\
\text { steps; } 10000 \\
\text { BP - present }\end{array}$ & $\begin{array}{l}\text { (Guiot and Kaniewski, 2015); OT-Med data catalog at } \\
\text { http://database.otmed.fr/geonetworkotmed/srv/eng/sea } \\
\underline{\text { rch - |54b9bf34-57ae-45ea-b455-9f90351e538f }}\end{array}$ \\
\hline SRTM30 & digital elevation model & elevation $^{b}$ & $30 \mathrm{~m}$ & 2000 & (NASA JPL, 2013); http://dds.cr.usgs.gov/srtm/ \\
\hline
\end{tabular}

a. In fact the CRU dataset provides \% sunniness, which must be subtracted from 100 to provide \% cloudiness.

b. Although they were not ultimately used, we also tested elevation derivatives, e.g., slope, aspect, and irradiance. 
Table 3: Monthly temperatures from HolCR and downscaling results for the study area at $2400 \mathrm{BP}$.

\begin{tabular}{|c|c|c|c|c|c|c|c|c|c|c|c|c|}
\hline & January & February & March & April & May & June & July & August & September & October & November & December \\
\hline HolCR value & 3.08 & 4.04 & 6.91 & 10.57 & 14.67 & 18.26 & 21.29 & 21.55 & 17.33 & 12.12 & 7.21 & 4.03 \\
\hline $\begin{array}{l}\text { spatial } \\
\text { minimum }\end{array}$ & -1.08 & -0.35 & 1.33 & 5.04 & 9.00 & 12.69 & 15.75 & 16.35 & 12.36 & 7.40 & 2.88 & 0.05 \\
\hline $\begin{array}{l}\text { spatial } \\
\text { maximum }\end{array}$ & 4.77 & 5.67 & 8.69 & 12.24 & 16.24 & 19.95 & 22.95 & 23.08 & 18.87 & 13.86 & 8.97 & 5.63 \\
\hline
\end{tabular}




\section{Figure}

Click here to download high resolution image

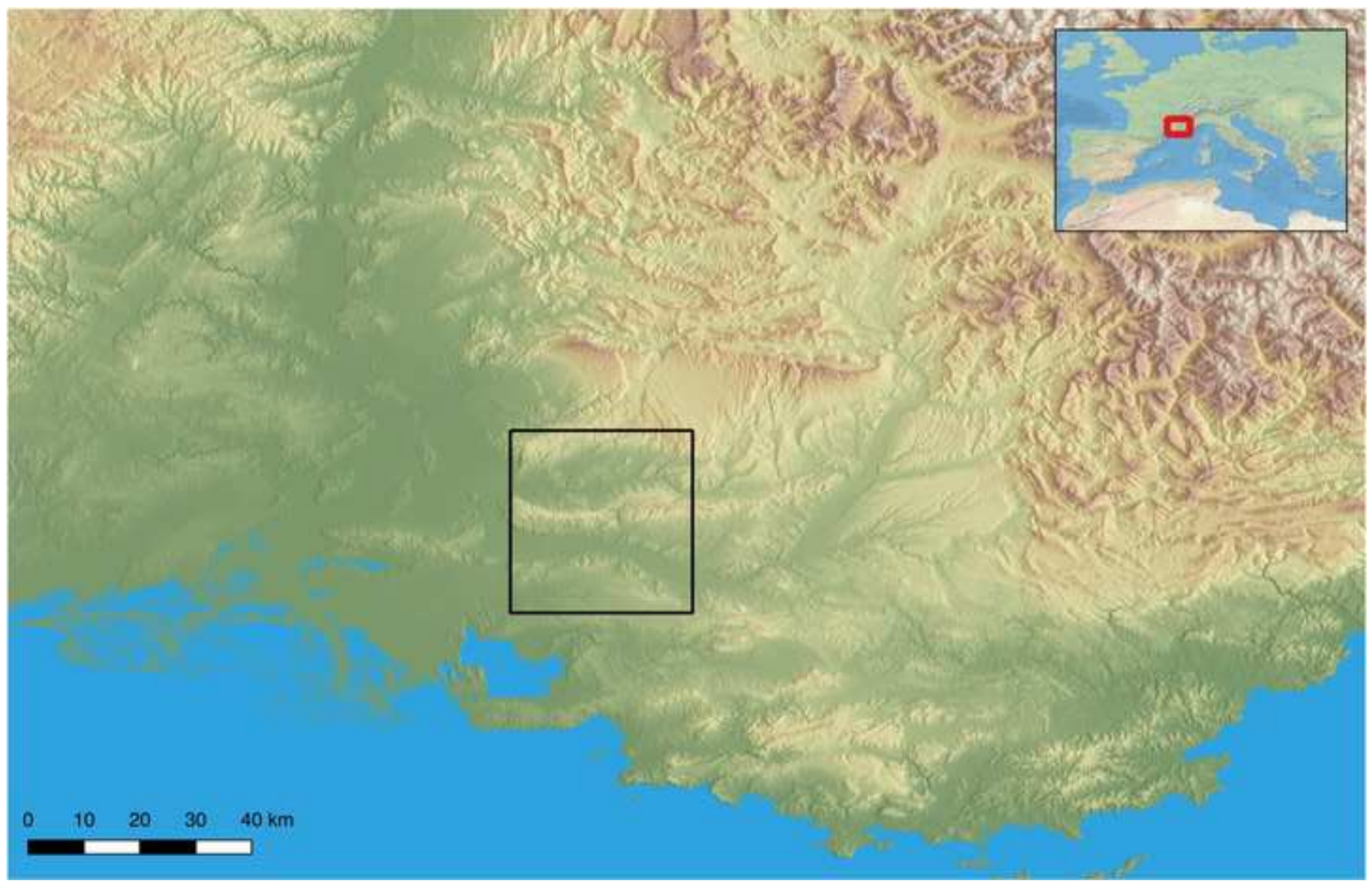




\section{Holocene ADT and TMP for the study area}

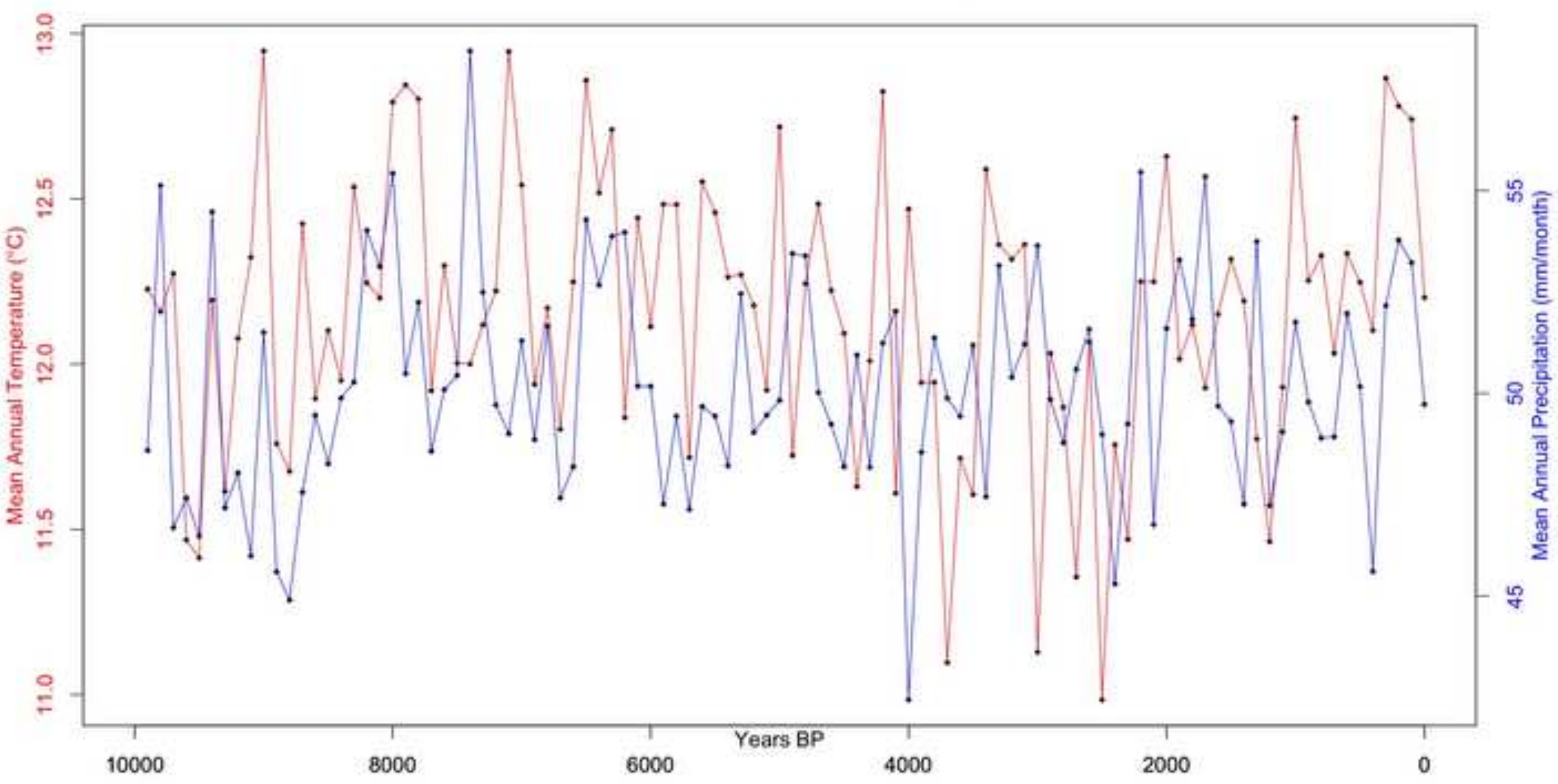


Click here to download high resolution image
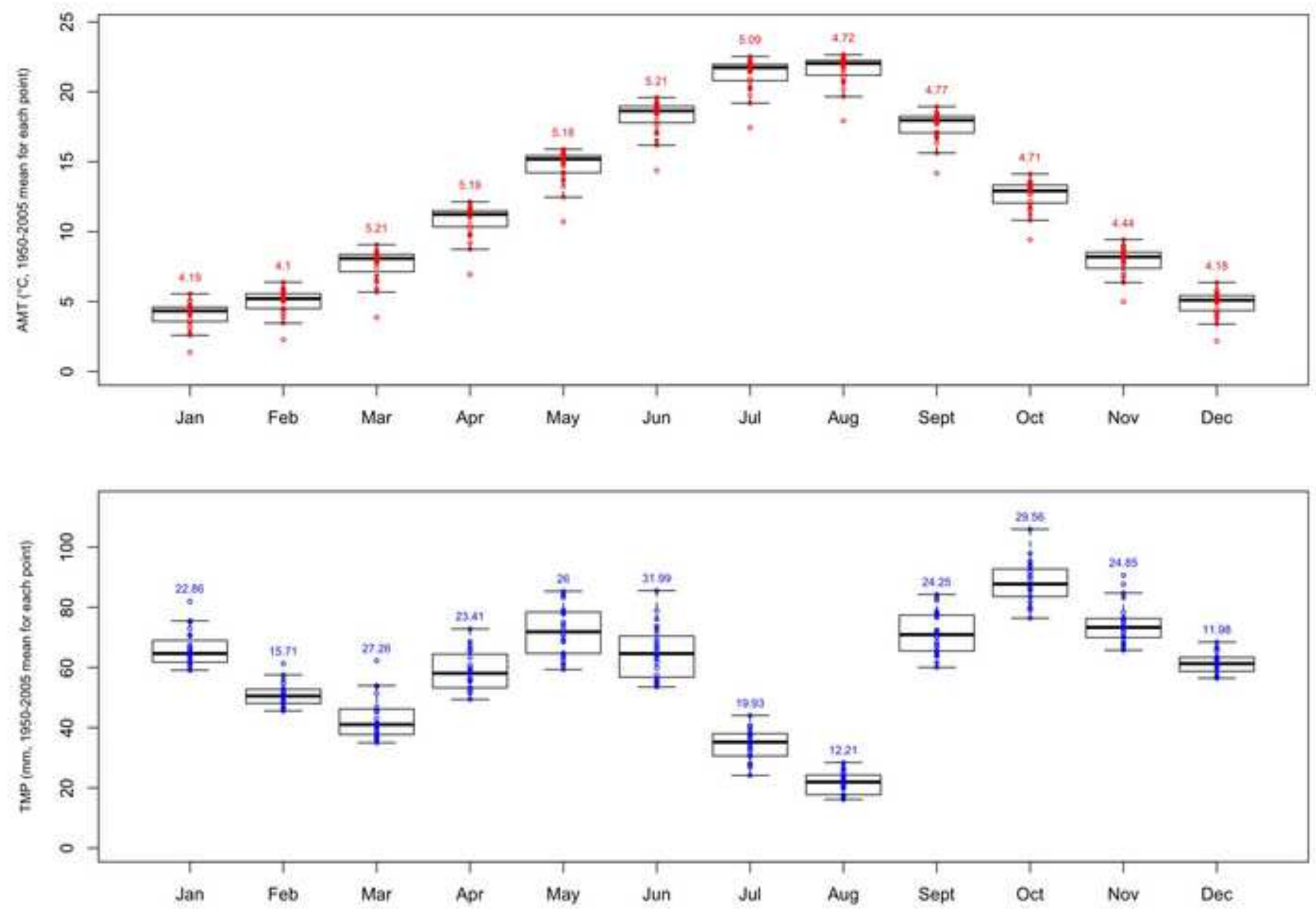

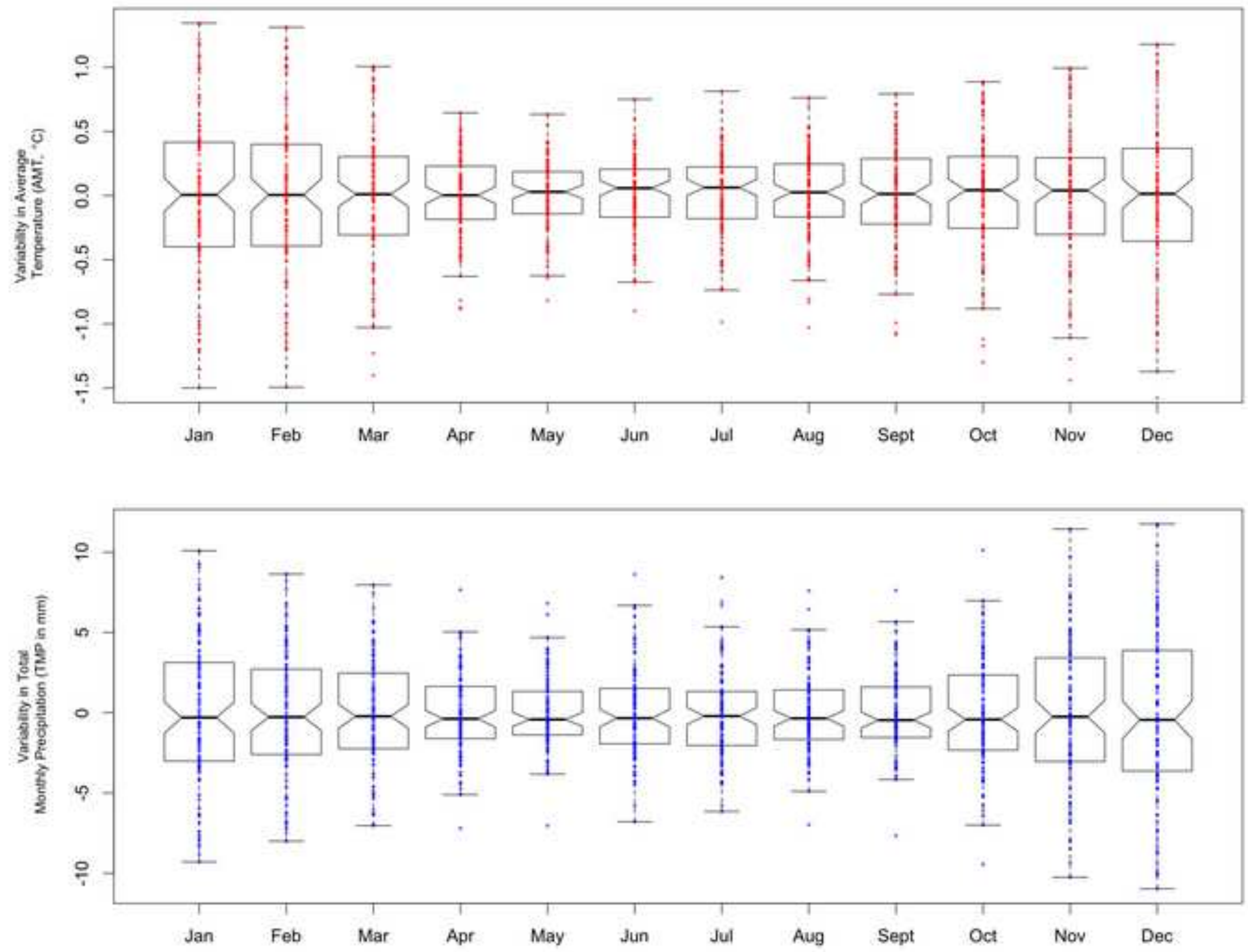
Click here to download high resolution image
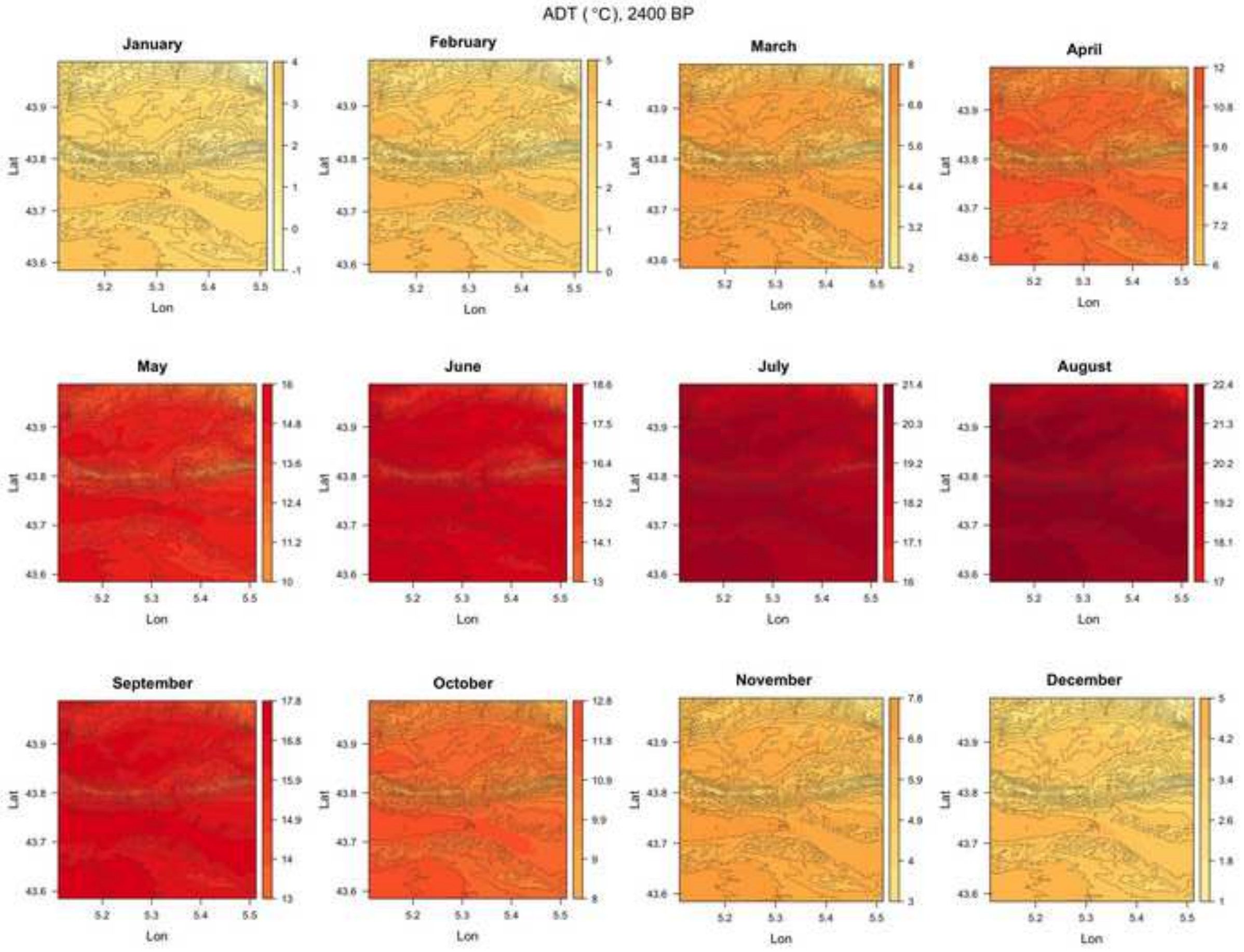


\section{Annual Temperature (Mean ADT)}

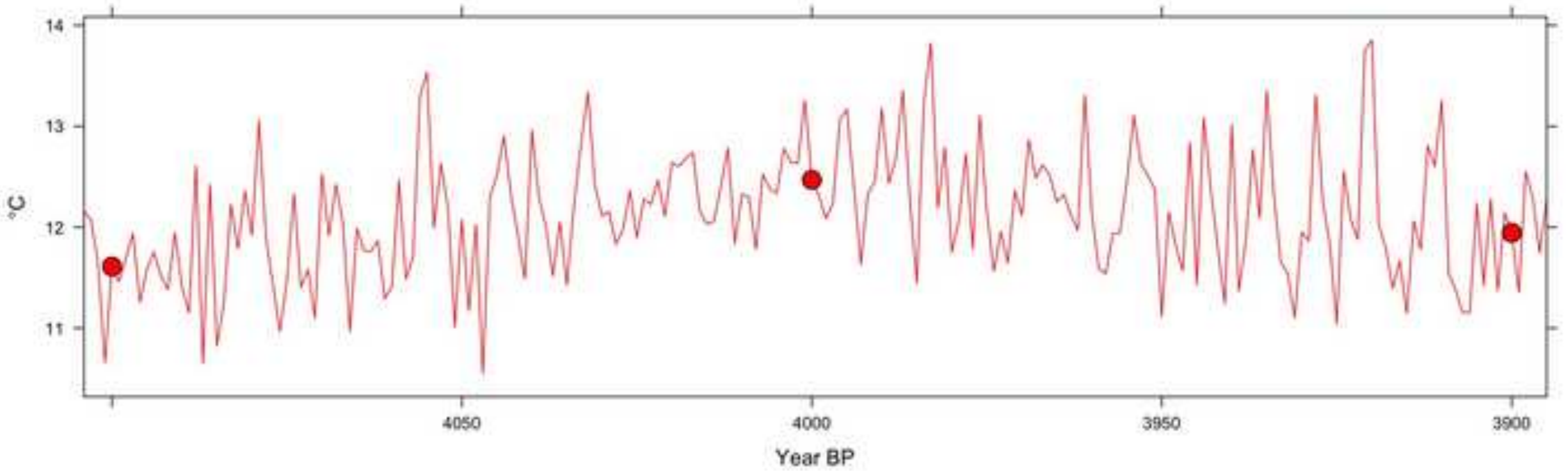

Annual Precipitation (Mean TMP in mm)

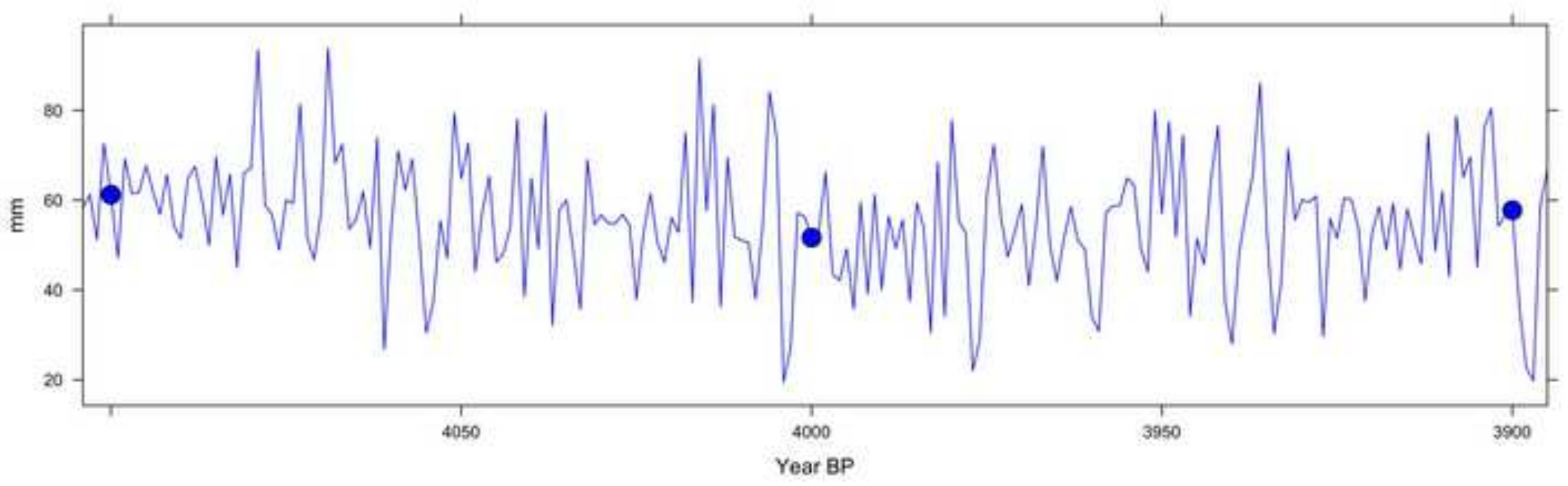




\section{Figure 7}

Click here to download high resolution image

a)

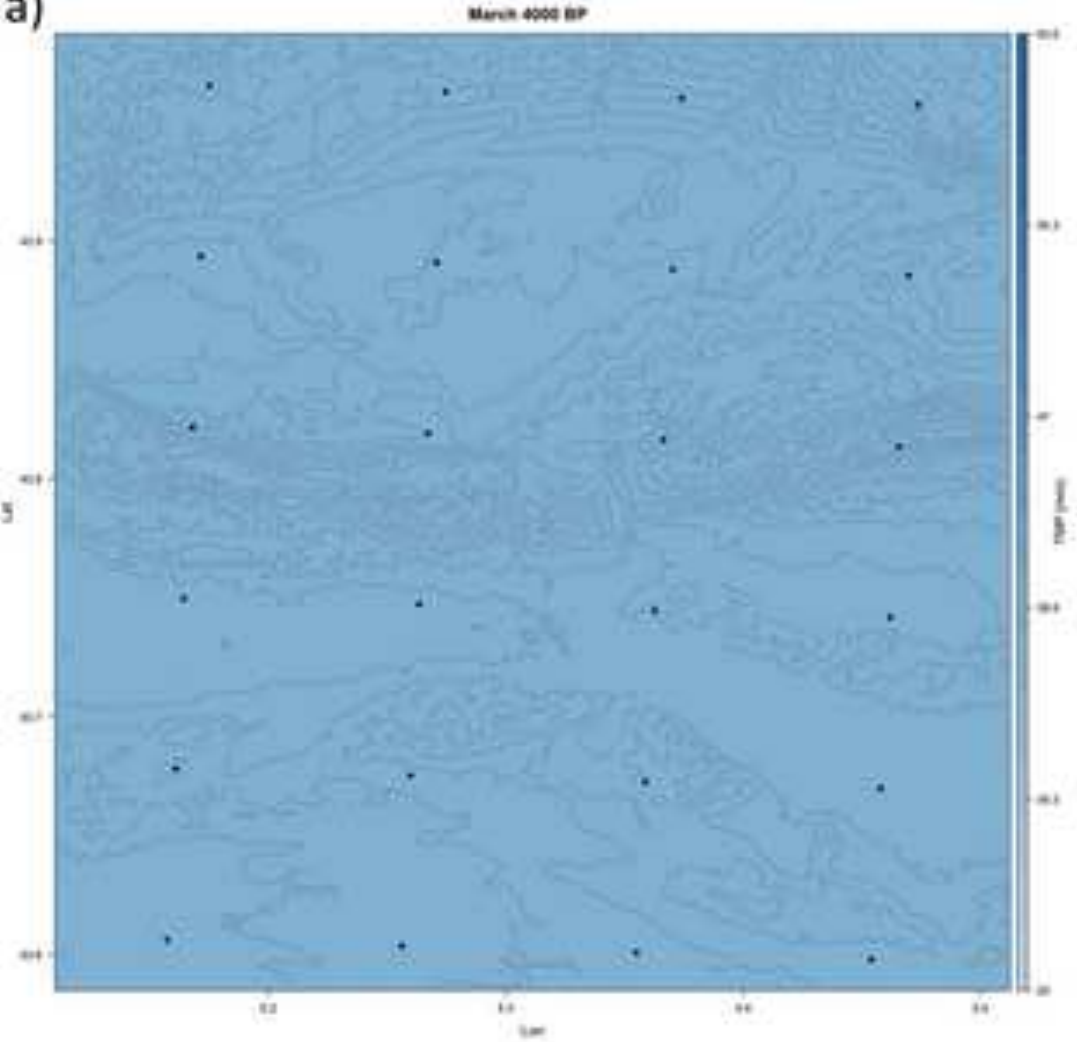

b)

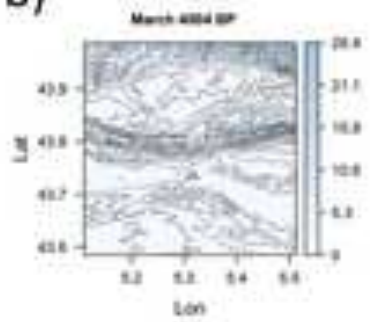

Undater

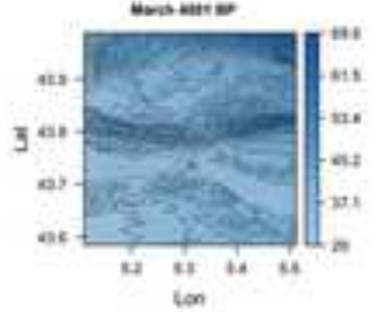

4at ana

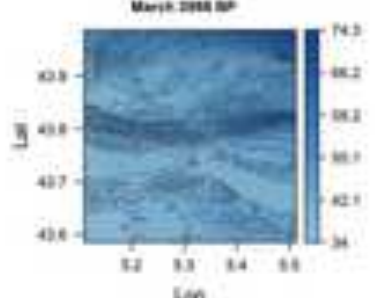

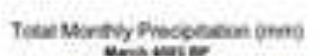

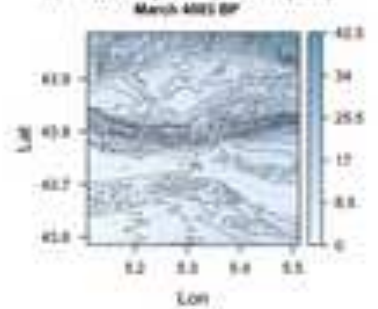

tond the

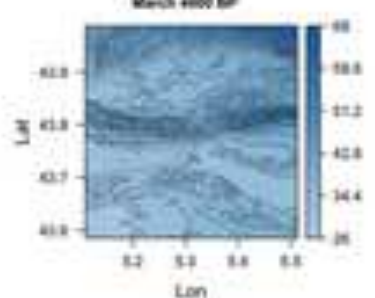

$m$ mant

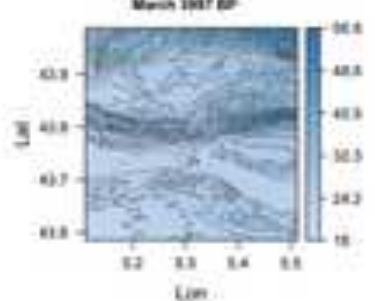

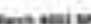

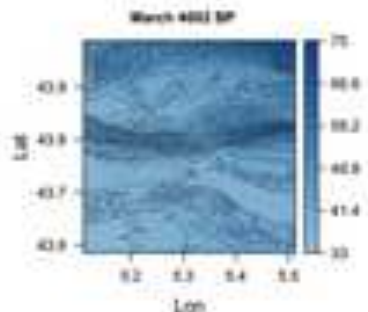

Losmin
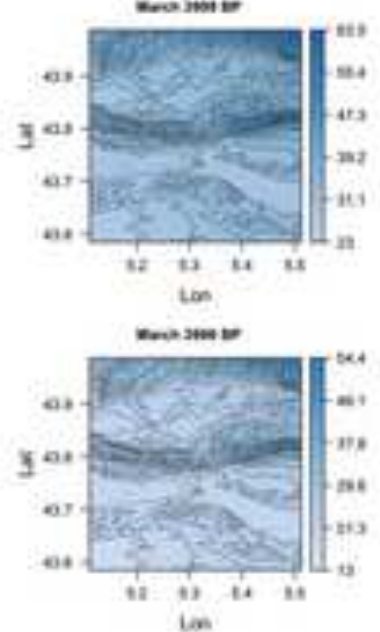


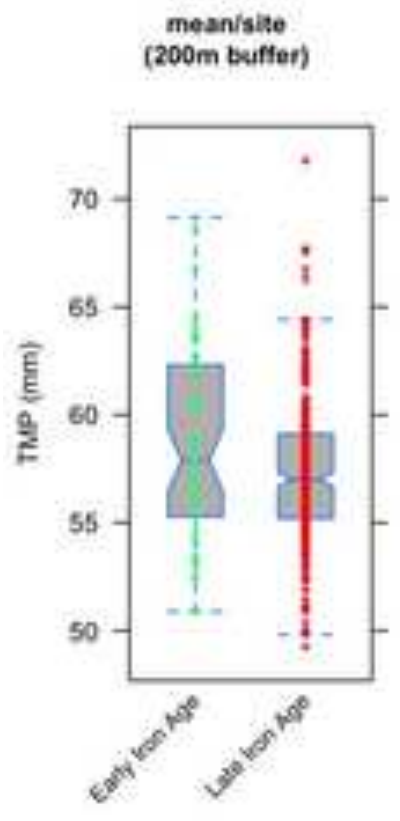

standard deviation'site (200m buffer)

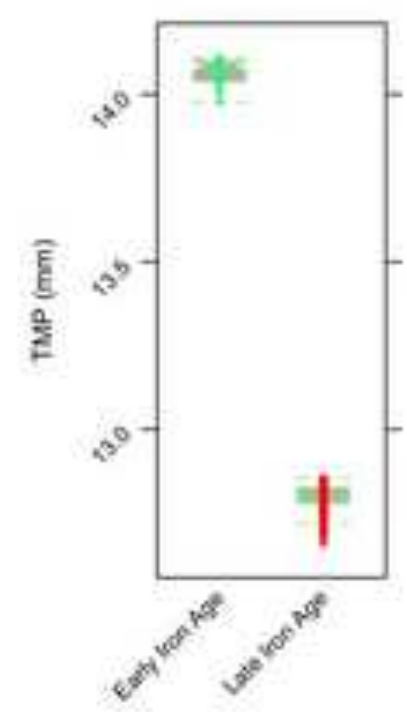

Mean Early Iron Age TMP

occupation \& agricultural sites

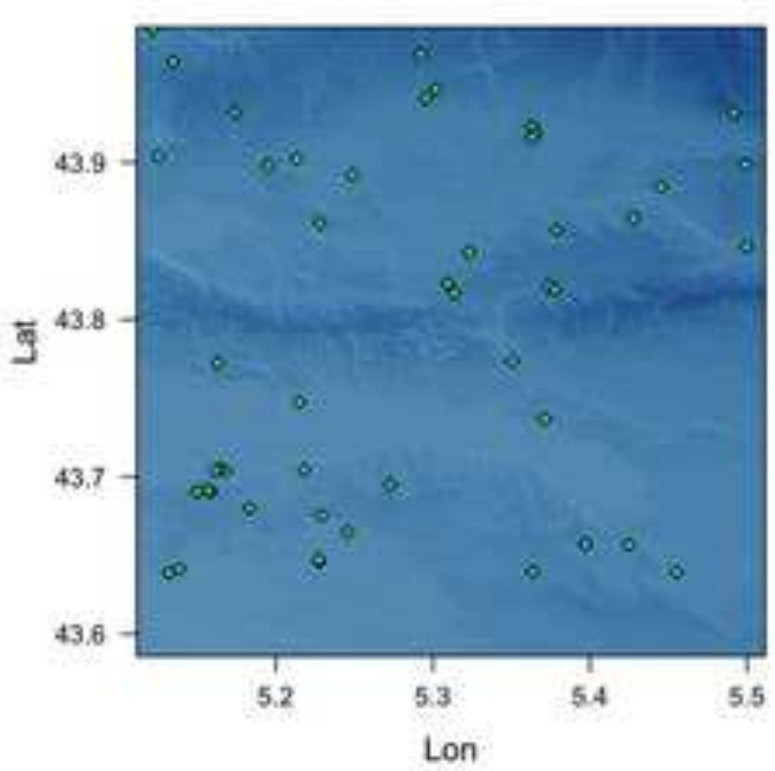

Standard Deviation in Early Iron Age TMP occupatian \& agricultural sites

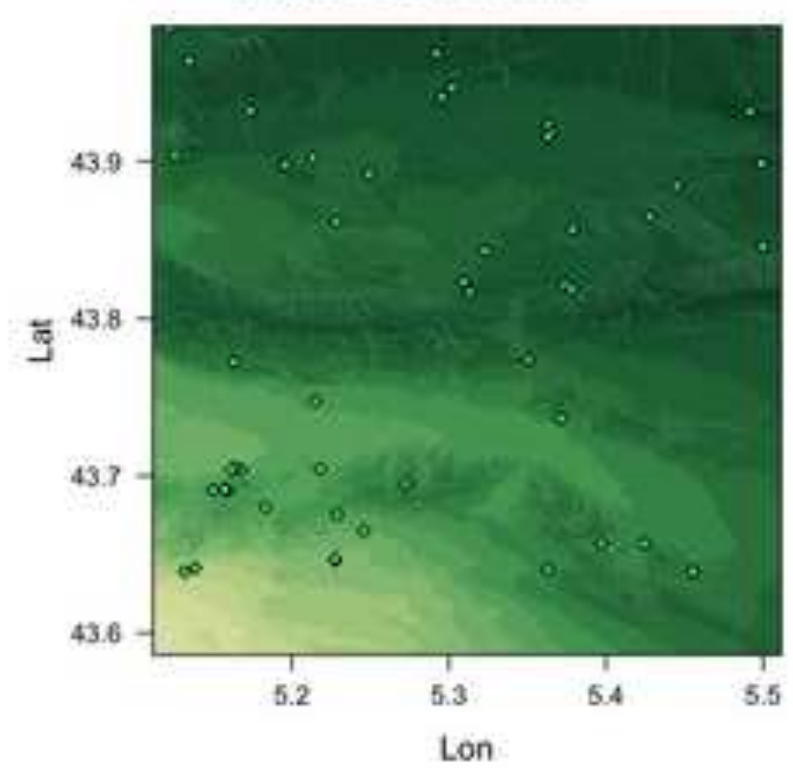

Mean Late Iron Age TMP

occupation s agricultural sites

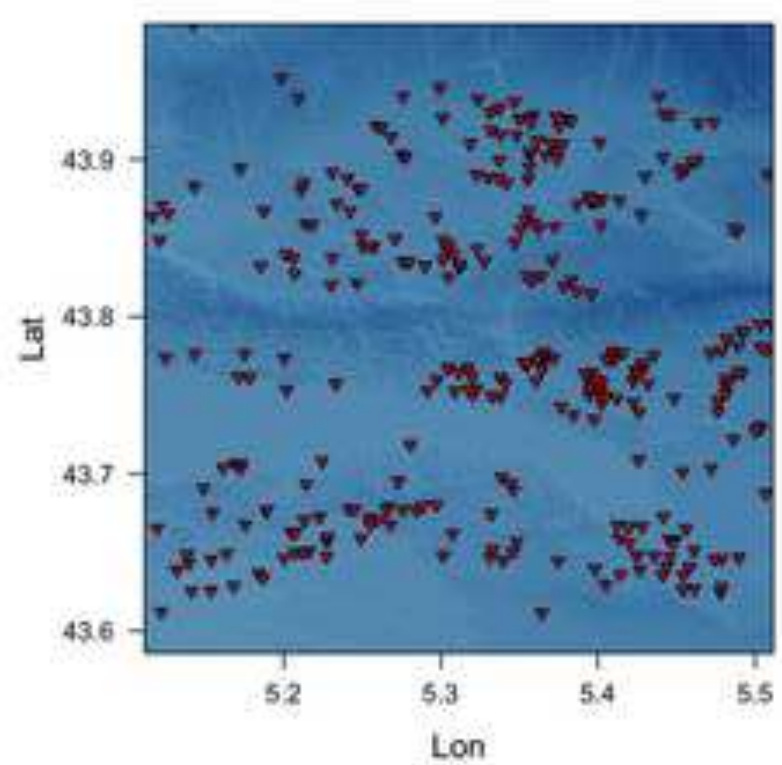

Standard Deviation in Late Iron Age TMP occupation \& agricultural sites

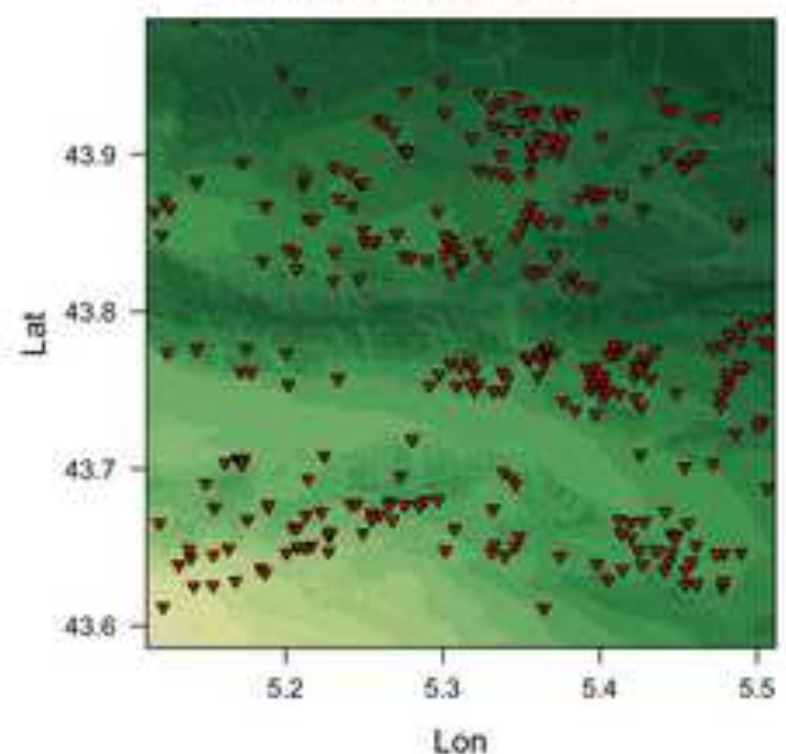


Supplementary Material - R code
Click here to download Supplementary Material: Rcode_forSI.r

Supplementary Material - R code
Click here to download Supplementary Material: Rcode_forSI.r

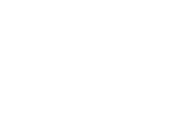

(n)

(1)

or

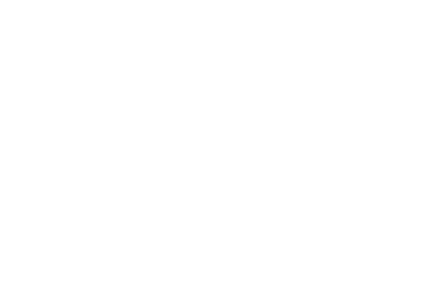

(1)

(1)

.

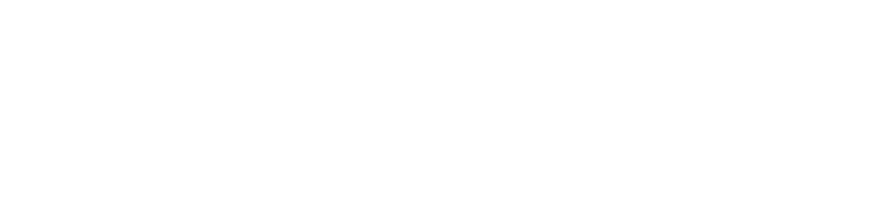

列

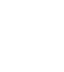

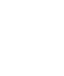

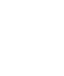

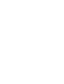

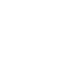

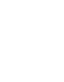

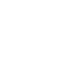

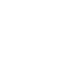

(1) 